$12-31-1972$

\title{
Interregional competition in the fresh apple industry
}

Kathleen Brain

Robert L. Jack

Follow this and additional works at: https://researchrepository.wvu.edu/ wv_agricultural_and_forestry_experiment_station_bulletins

\section{Digital Commons Citation}

Brain, Kathleen and Jack, Robert L., "Interregional competition in the fresh apple industry" (1972). West Virginia Agricultural and Forestry Experiment Station Bulletins. 612T.

https://researchrepository.wvu.edu/wv_agricultural_and_forestry_experiment_station_bulletins/706 @ WVU. It has been accepted for inclusion in West Virginia Agricultural and Forestry Experiment Station Bulletins by an authorized administrator of The Research Repository @WVU. For more information, please contact ian.harmon@mail.wvu.edu. 


\section{terregional Competition}

the Fresh Apple Industry
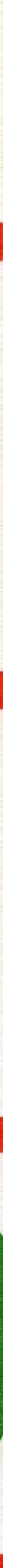
[Blank Page in Original Bulletin] 


\section{Interregional Competition}

\section{In The Fresh Apple Industry}

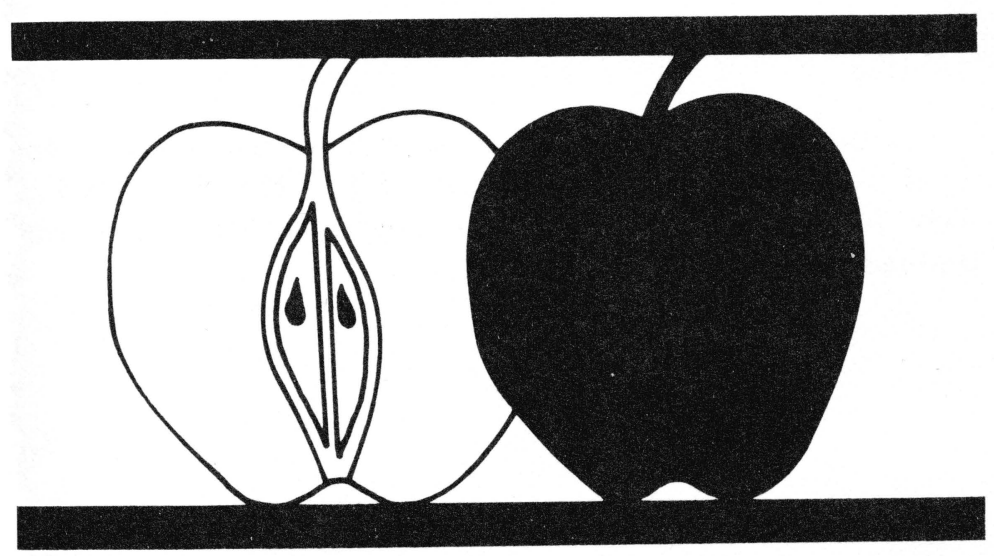

WEST VIRGINIA UNIVERSITY

AGRICULTURAL EXPERIMENT STATION 


\section{THE AUTHORS}

At the time of this study Kathleen Brain was a Graduate Research Assistant in Agricultural Economics; Robert L. Jack is Associate Agricultural Economist.

This bulletin is published as a contribution to the Northeast Regional Marketing Research Project (NEM-41). The West Virginia research for this publication was supported by both state and regional research funds.

West Virginia University Agricultural Experiment Station College of Agriculture and Forestry

R. S. Dunbar, Jr., Director Morgantown 


\section{CONTENTS}

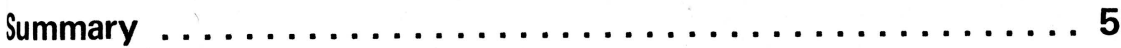

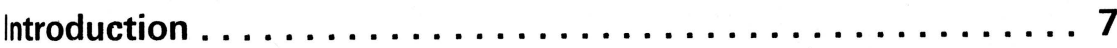

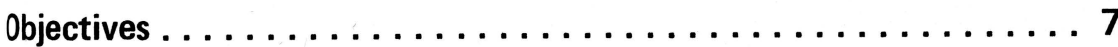

The Model $\ldots \ldots \ldots \ldots \ldots \ldots \ldots \ldots \ldots \ldots \ldots \ldots$

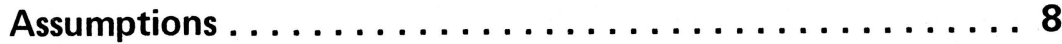

Basic Data . . . . . . . . . . . . . . . . . . 8

Demarcation of Regions . . . . . . . . . . . . 8

Population .................... 8

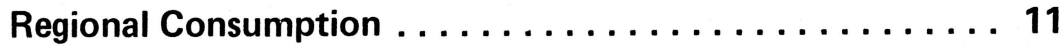

Transportation Rates $\ldots \ldots \ldots \ldots \ldots \ldots \ldots \ldots \ldots$

Acreage Constraints . . . . . . . . . . . . . . . 14

Production Costs ....................... 14

Yields ............................ 15

The Basic Model . . . . . . . . . . . . . . . . . . . . . . . . . . . . . . 15

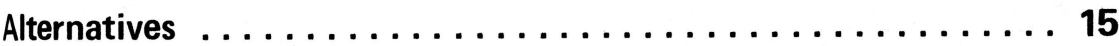

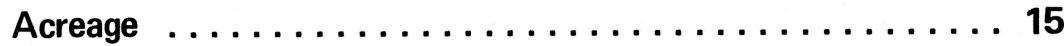

Transportation .................. 17

Production Costs . . . . . . . . . . . . . . . . . 18

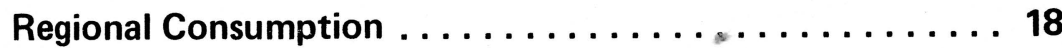

Model Results . . . . . . . . . . . . . . . . . . . . . . . 20

Basic Model . . . . . . . . . . . . . . . . . . . 20

Alternative I . . . . . . . . . . . . . . . . 22

Alternative II .................... 22

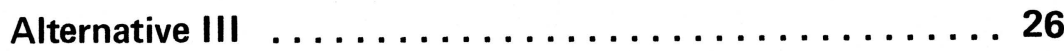

Alternative IV ................... 28

Alternative $\mathrm{V} \ldots \ldots \ldots \ldots \ldots \ldots \ldots \ldots \ldots \ldots \ldots \ldots$

Alternative $\mathrm{VI} \ldots \ldots \ldots \ldots \ldots \ldots \ldots \ldots \ldots \ldots \ldots$

Shadow Prices . . . . . . . . . . . . . . . . . . . . 34

Cost of Forced Shipment . . . . . . . . . . . . . . 38

Conclusions and Implications $\ldots \ldots \ldots \ldots \ldots \ldots \ldots \ldots \ldots \ldots 41$

References ........................ 42

Appendix ...................... 47 



\section{SUMMARY}

Many changes have affected the market structure and competition in the fresh apple industry since the turn of the century, such as increased yields, mechanization, improved transportation, and population shifts. In this study an attempt was made to develop an interregional competition model which would determine the least-cost allocation of the commercial fresh apple supply over the United States.

In the analysis, the United States was divided into 22 consumption regions; nine of these regions were dually classified as consumption and production regions. Aggregate regional consumption, truck rates, available cropland, and production costs were used to construct the Basic Model. This was solved using the MPS-360 computer routine to determine the least-cost production and allocation of the fresh apple supply. Alternative solutions involved variations in acreage constraints, transportation rates, production costs, and projection of consumption to 1985 .

The solution of the Basic Model showed all nine production regions with excess acreages. New England, Washington, and Oregon, which had higher costs per unit of production than the other regions, did not enter into fresh apple production in this solution. The spatial flow pattern was generally east to west with Virginia having the largest number of acres in fresh apple production. When acreage currently used in total apple production was used for the maximum acreage constraints (Alternative 1), there was no change in the direction of flow or the regions engaged in fresh apple production. However, the aggregate production and transportation costs increased slightly over the Basic Model because there was some reallocation with Pennsylvania and Virginia producing more and West Virginia producing less.

In Alternative II, where the maximum acreage constraints were reduced by the percentage of total àpple production from each of the commercial production regions which was consumed as fresh apples, the flow pattern was basically west to east. Of the eight regions which produced, only Washington had surplus acreage, but Washington was the largest producer in terms of acreage and production. Oregon was the only region which did not produce fresh apples. Because this solution showed flows and production patterns similar to those existing in the apple industry, it was used as a standard of comparison for the remaining alternatives.

The maximum acreage constraints of Alternative 11 were reduced $10 \mathrm{per}$ cent for Alternative III. All regions except Washington and Oregon used their entire acreage constraint in Alternative II. Therefore, the 10 per cent decrease in available acreage caused a decrease in fresh apple production in all regions except Washington and Oregon. This was compensated for by increased production in Washington while Oregon, again, did not produce fresh apples. The spatial flow pattern for Alternative III was similar to that of Alternative II, but the aggregate production and transportation costs increased 6.9 million dollars due to the higher production and transportation costs for apples produced in Washington. 
In Alternative IV, all transportation costs were reduced 10 per cent, but there was little change from the spatial flow pattern of Alternative II. Acreages in fresh apple production in each region were the same as in Alternative II. A 10 per cent reduction in production costs in Washington, Oregon, and California (Alternative $V$ ) did not change the level of production or west-to-east flow of fresh apples from Alternative II. In fact, the only difference in the two solutions was a $\mathbf{5 . 3}$ million dollar decrease in aggregate cost in Alternative $\mathrm{V}$.

In Alternative VI, regional consumption was projected to decrease by 1985 in 21 of the 22 consumption regions. This caused total fresh apple consumption to decrease despite increasing population. The direction of flow in the optimal solution was principally east to west, with Michigan the largest producer in terms of both acreage and cartons of apples. In this alternative, production decreased in Washington and New England from Alternative II but remained constant in the other seven production regions.

Of those regions with restricted acreages, shadow prices on limited acreages ${ }^{1}$ showed that an additional acre of production in Michigan would decrease aggregate costs by the largest amount and an additional acre in New England would decrease aggregate costs by the least amount. Washington and Oregon had acreage excesses in all solutions, which indicated these two regions were at a competitive disadvantage relative to the other seven production regions when production, transportation costs, and consumption were considered. Shadow prices on the 22 consumption regions showed that, in general, as acreage was decreased, shadow prices increased and as costs or consumption decreased, shadow prices also decreased.

Costs of forced shipments from West Virginia and Washington to all 22 consumption regions were determined. Generally, in alternatives where costs of forced shipments from Washington increased, there were simultaneous decreases in costs of forced shipments from West Virginia, and vice versa.

${ }^{1}$ The amount by which aggregate cost would be reduced if one additional acre were brought into production. 


\section{Interregional Competition}

\section{In The Fresh Apple Industry}

\section{Kathleen Brain and Robert L. Jack}

Development and adoption of new technologies have changed the market structure and competition in the fresh apple industry since the turn of the century. For example, new varieties of apples, chemicals, and better management practices have made it possible to increase yields per acre. Increased mechanization of the apple industry and the high fixed costs associated with mechanization have led to gradual establishment of large scale farms with a high degree of specialization by region and varieties of apples. Refrigeration and improved transportation now allow producers to place high quality apples in any market in the world. These changes have increased competition among all fresh apple producers.

Expanding population on the west coast and a few southern states coupled with relatively stable population in the Northeast has caused a gradual shift in the population center toward the southwest. Because of this shift and declining per capita consumption, the demand for fresh apples is decreasing in the Northeast and it is increasing in those areas where population is increasing.

\section{OBJECTIVES}

The purpose of this study was to develop an interregional competition model which would determine efficient allocations of commercial fresh apple production over the United States ${ }^{2}$ and analyze the possible effects of alternative market conditions on the industry. The specific objectives were (1) to develop a model for analyzing interregional competition and least-cost allocation for commercial fresh apple production; (2) to determine optimal regional land use for fresh apple production; and (3) to analyze the possible effects of changes in (a) population and per capita consumption and (b) the transportation rate structure for shipment of fresh apples.

\section{The Model}

A linear programming interregional competition model was constructed to obtain the least-cost flow of fresh apples from nine spatially separated production regions to 22 consumption regions in the United States. The model assumes that quantities supplied and/or demanded are known for each region and that all regions are connected by known transportation costs. ${ }^{3}$ By inserting

${ }^{2}$ Alaska and Hawaii excluded.

${ }^{3}$ Earl O. Heady and Wilfred Chandler, Linear Programming Methods (Ames, lowa: The Iowa State University Press, 1958) pp. 332-377. 
information based on these assumptions the model was solved to show the volume and direction of flow of fresh apples which would minimize total production and transportation costs. Alternative solutions were examined to determine the effects of changes in factors influencing transportation rates, supply, and demand.

\section{Assumptions}

The model assumed that consumption in each region was known or could be derived. Homogeneity of product was assumed, therefore no preference existed for apples produced in any one production region. Apples were produced only in the designated production regions. Since this study involved only fresh apple production, it was assumed that the entire acreage allotment for each region was available for fresh as opposed to processing apple production. Each production region was connected with all consumption regions by known transportation costs which were independent of the quantity shipped. The fresh apple industry was assumed competitive and prices between regions differed only by the unit cost of transporting apples from the point of production to the point of consumption. The production capacity of each production region was a non-negative value which was known. It was also assumed that domestic supply equaled domestic demand.

Given these specifications, a model was constructed which specified the optimal level and distribution of production for each production region.

\section{BASIC DATA}

\section{Demarcation of Regions}

The United States was divided into 22 consumption regions, the smallest being a single state. Each consumption region was represented by one city selected on the basis of population concentration and proximity to the geographical center of the region (Figure 1). Nine of the regions were dually classified as consumption and production regions. These production regions coincided with the commercial apple production regions defined by the United States Department of Agriculture (USDA). ${ }^{4}$ Each production region was represented by a city located in or near a major apple-producing area within the region (Figure 2 ). In the nine regions which were simultaneously defined as consumption and production regions one city represented regional consumption and another was the origin of supply. Only in these situations were intra-regional shipments considered.

\section{Population}

Consumption data are generally available on a per capita basis; therefore regional populations were necessary to obtain estimated regional consumption ${ }^{4}$ U. S. Department of Agriculture, Agricultural Statistics, 1970 (Washington: U. S. Government Printing Office, 1970), p. 211. 


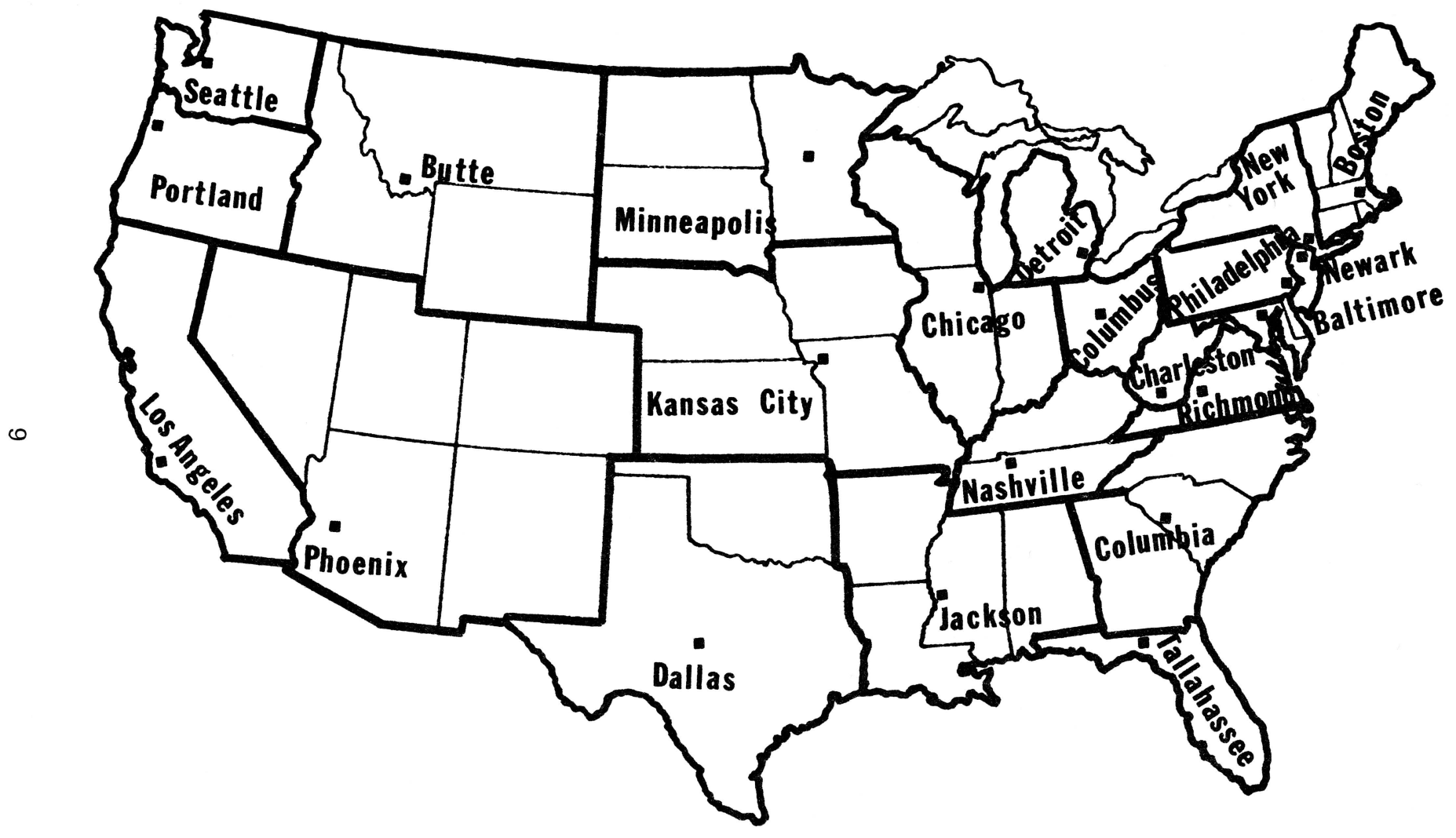

Figure 1. Demarcation of 22 Consumption Regions and Points Representing Consumption 


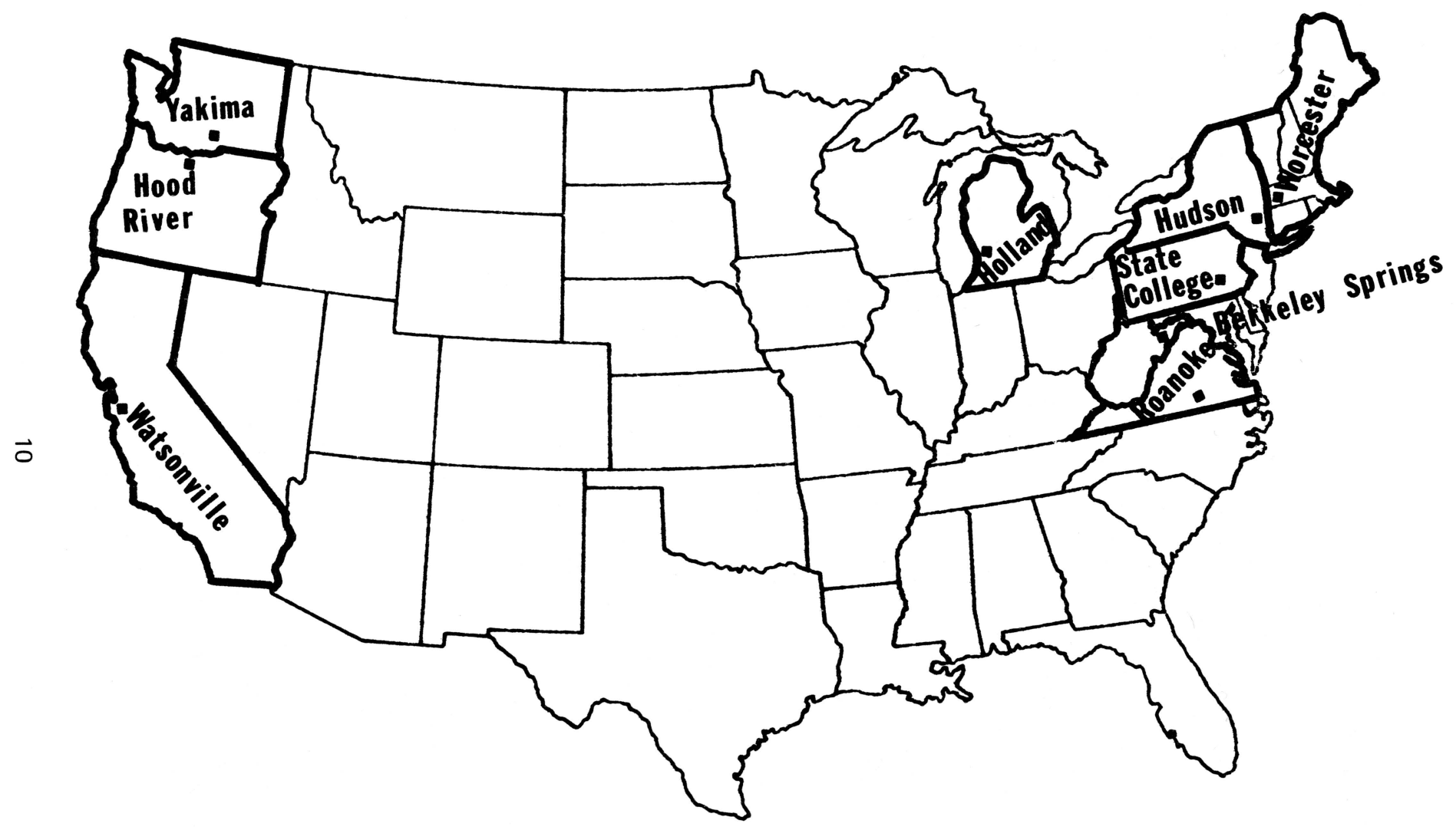

Figure 2. Demarcation of Nine Commercial Apple Production Regions and Points Representing Supply 
on an aggregate basis. Preliminary population figures by states for 1969 were used to estimate the populations in the 22 consumption regions. ${ }^{5}$

\section{Regional Consumption}

The Economic Research Service (ERS) has estimated per capita fresh apple consumption for a number of years by dividing the total apparent civilian consumption by total population adjusted for members of the armed forces not eating out of the civilian supplies. Using this method of estimation, per capita fresh apple consumption has decreased 60 per cent over the last 20 years.

Nationwide household consumption surveys conducted by the Agricultural Research Service (ARS) in 1955 and 1965-66 indicated increased per capita fresh apple consumption from 1955 to 1965 in all of the survey regions. The information provided by the ARS surveys was used to adjust the 1969 annual ERS per capita fresh apple consumption estimate for regional consumption differences.

The ARS regional and overall United States consumption estimates are given as weekly consumption per household. After these figures were converted to an annual per capita basis, the regional consumption was expressed as a percentage of the overall United States per capita consumption estimate for each year of the survey (Appendix Table A). For each survey region the mean of the two percentages was calculated and the resulting figures, listed below, were used to adjust the 1969 ERS United States per capita consumption estimate of 15 pounds for regional differences.

Northeast $\quad 104.0$ per cent

North Central 110.0 per cent

West $\quad 107.5$ per cent

South $\quad 85.5$ per cent

The 1969 adjusted per capita consumption estimates for the four ARS regions were: Northeast, 15.6 pounds; North Central, 16.5 pounds; West, 16.1 pounds; South, 12.8 pounds.

Regional fresh apple consumption (Table 1) was calculated by multiplying regional population by the appropriate per capita consumption estimate. The resultant figures were converted to a 46-pound carton basis (Appendix Table B).

\section{Transportation Rates}

In the present study trucking rates were used to reflect the transportation rate structure for fresh apples. Since truck rates for moving fresh apples are exempt from Interstate Commerce Commission regulation, rate information was obtained by writing to producers and brokers. This information was used to estimate transportation rates between points for which no data were available.

${ }^{5}$ U. S. Department of Commerce, Statistical Abstract of the United States, 1970 (Washington: U.S. Government Printing Office, 1970), p. 12.

${ }^{6}$ U. S. Department of Agriculture, loc. cit., p. 258. 
TABLE 1

REGIONAL POPULATION AND FRESH APPLE CONSUMPTION ESTIMATES

\begin{tabular}{|c|c|c|}
\hline $\begin{array}{l}\text { Consumption } \\
\text { Region }\end{array}$ & \multirow{2}{*}{$\begin{array}{c}\begin{array}{c}1969 \text { Preliminary } \\
\text { Population }\end{array} \\
\text { (thousands) }\end{array}$} & \multirow{2}{*}{$\begin{array}{c}\begin{array}{c}\text { Estimated } \\
\text { Consumption }^{b} \\
\text { (cartons) }\end{array} \\
\text { (ten thousands) }\end{array}$} \\
\hline & & \\
\hline 1 New England & 11,512 & 390.4 \\
\hline $2 N Y$ & 18,321 & 621.3 \\
\hline 3 PA & 11,803 & 400.0 \\
\hline $4 \mathrm{NJ}$ & 7,148 & 242.4 \\
\hline 5 DE-MD & 5,103 & 142.0 \\
\hline 6 WV & 1,819 & 50.6 \\
\hline $7 \mathrm{VA}$ & 4,669 & 129.9 \\
\hline 8 NC-SC-GA & 12,538 & 348.9 \\
\hline $9 \mathrm{FL}$ & 6,354 & 176.8 \\
\hline $10 \mathrm{MI}$ & 8,766 & 314.4 \\
\hline 11 WI-IL-IN & 20,398 & 731.7 \\
\hline $12 \mathrm{OH}$ & 10,740 & 385.2 \\
\hline $13 \mathrm{KY}-\mathrm{TN}$ & 7,217 & 200.8 \\
\hline 14 AR-LA-MS-AL & 11,631 & 323.6 \\
\hline 15 ND-SD-MN & 4,974 & 178.4 \\
\hline 16 NE-IA-KS-MO & 11,202 & 401.8 \\
\hline 17 OK-TX & 13,755 & 382.7 \\
\hline 18 MT-ID-WY & 1,732 & 60.2 \\
\hline 19 NV-UT-CO-AZ-NM & 5,295 & 185.3 \\
\hline 20 WA & 3,402 & 119.0 \\
\hline $21 \mathrm{OR}$ & 2,032 & 71.1 \\
\hline $22 \mathrm{CA}$ & 19,443 & 680.5 \\
\hline TOTALS & 199,854 & $6,537.1$ \\
\hline
\end{tabular}

asources: U. S. Department of Commerce, Statistical Abstract of the United States, 1970 (Washington: U. S. Government Printing Office, 1970), p. 12.

${ }^{b}$ See Appendix Table B for estimating procedure. 
The data were partitioned into nine groups based on origin and direction of shipment in consideration that transportation rates might vary depending on origin and direction of shipment. Mileages between all pairs of production and consumption points for which actual transportation rates were available were obtained from the Household Goods Carriers' Bureau. ${ }^{7}$ For each group a simple regression using mileage as the independent variable was fit to existing rate data. The resultant equations are given in Table 2. All nine equations were significant at the .01 level and were used to predict transportation rates for those situations where actual rates were not available.

Transportation rates per 46-pound carton between all possible pairs of production and consumption regions are listed in Appendix Table $\mathrm{C}$.

7Household Goods Carriers' Bureau, Mileage Guide No. 9 (Washington, 1967).

\section{TABLE 2}

\section{EQUATIONS FOR ESTIMATING TRANSPORTATION RATES}

\begin{tabular}{|c|c|c|c|c|c|}
\hline $\begin{array}{l}\text { Direction of } \\
\text { Shipment }\end{array}$ & $\begin{array}{l}\text { Sample } \\
\text { Size }\end{array}$ & $\begin{array}{l}\text { Equation } \\
\text { Number }\end{array}$ & Prediction Equation $^{a}$ & F-Ratio ${ }^{b}$ & $\mathrm{R}^{2}$ \\
\hline East to North & 23 & 1 & $\mathrm{C}=.30189+\underset{(.00005)}{.00062 m}$ & 150.73 & .88 \\
\hline East to South & 33 & 2 & $C=.26095+\frac{.00036 m}{(.00004)}$ & 71.49 & .70 \\
\hline East to East & 10 & 3 & $\mathrm{C}=.13844+\underset{(.00009)}{.00087 m}$ & 100.52 & .93 \\
\hline East to West & 40 & 4 & $C=.35825+\frac{.00033 m}{(.00004)}$ & 83.30 & .69 \\
\hline West to South & 26 & 5 & $C=.14992+\underset{(.00003)}{.00047 m}$ & 337.12 & .93 \\
\hline West to East & 102 & 6 & $C=.23212+\underset{(.00044 m}{.0002)}$ & 522.94 & .84 \\
\hline Michigan to South & 47 & 7 & $C=.28884+\underset{(.00002)}{.00026 m}$ & 119.69 & .82 \\
\hline Michigan to East & 21 & 8 & $C=.30718+\underset{(.00003)}{.00037 m}$ & 168.12 & .90 \\
\hline Michigan to West & 23 & 9 & 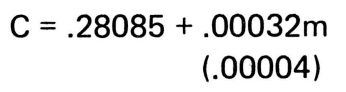 & 205.15 & .91 \\
\hline
\end{tabular}

${ }^{a} \mathrm{C}$ is the total transportation rate per 46-pound carton; $m$ is the mileage between the two points under consideration. Numbers in parentheses are the standard error of the regression coefficient.

${ }^{b}$ All F-ratios were significant at the .01 level with $(1, N-2)$ degrees of freedom. 


\section{Acreage Constraints}

In the Basic Model preliminary 1964 estimates of cropland and nonforested permanent pasture by states were used as maximum acreage constraints for fresh apple production in the nine production regions (Table 3). This was done so that only land available for agricultural uses could be assigned to potential fresh apple production. Without such a constraint it would be possible for the Basic Model solution to allocate all acreage in an entire production region to fresh apple production, inlcuding land presently urbanized or otherwise not available for agricultural activities.

\section{Production Costs}

Production cost data for apples were available for all production regions except Virginia and West Virginia. Because of the proximity of these production regions to Pennsylvania and the similarity of production conditions, production costs of that state were used to reflect Virginia and West Virginia production costs as well.

Cost data received from production regions were standardized by grouping all costs into seven cost items which were then updated to 1970 by use of appropriate price indexes. Table 4 gives the adjusted production costs for the seven regions for which data were available.

\section{TABLE 3}

\section{MAXIMUM ACREAGE CONSTRAINTS USED IN THE BASIC MODEL FOR NINE COMMERCIAL APPLE PRODUCING REGIONS ${ }^{a}$}

\begin{tabular}{lc}
\hline \hline Production Region & Acreage $^{\mathbf{b}}$ \\
\hline & (thousands) \\
New England & 3,584 \\
New York & 8,928 \\
Pennsylvania & 7,833 \\
West Virginia & 2,843 \\
Virginia & 6,648 \\
Michigan & 10,444 \\
Washington & 14,926 \\
Oregon & 17,002 \\
California & 32,291 \\
\hline
\end{tabular}

\footnotetext{
a Source: United States Department of Agriculture, Agricultural Statistics, 1967 (Washington: U.S. Government Printing Office, 1967), p. 513.

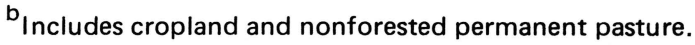




\section{TABLE 4}

\section{PER ACRE PRODUCTION COSTS FOR SEVEN MAJOR APPLE PRODUCING STATES, ADJUSTED FOR 1970}

Per Acre

Production Region

Production Cost, Adjusted for 1970

Maine

New York

Pennsylvania

Michigan

Washington

Oregon

California
$\$ 624.10$

484.65

455.52

623.16

$1,008.23$

$1,225.70$

$1,389.75$

${ }^{\mathrm{a}}$ Taken from Appendix Table D.

Yields

Yields were based on information supplied by research studies in the production regions. Due to lack of such information for Virginia and West Virginia, Pennsylvania yields also were used in these two regions. Since transportation rates are given in terms of 46-pound cartons, it was necessary to convert yields to this measurement (Table 5 ).

\section{THE BASIC MODEL}

The data previously described were used to construct the Basic Model. The solution to the model is the least-cost allocation of the fresh apple supply, given estimated regional consumption, transportation rate structure, production costs, and maximum capacity for regional agricultural production.

\section{ALTERNATIVES}

\section{Acreage}

Three sets of acreage constraints were used in the model in an attempt to find a solution which reflected the recent direction of flow of fresh apples. Alternatives I, II, and III were the same as the Basic Model except for the maximum acreage constraints. In Alternative $I$ the maximum acreage constraint was the estimated actual total acreage planted in apples in each of the nine production regions. For Alternative II the per cent of the total commercial apple production that was consumed fresh in 1969 was calculated for each production region. The acreage constraints in Alternative I were then multiplied by these percentages to arrive at the Alternative II acreage constraints. The 


\section{TABLE 5}

\section{APPLE YIELDS FOR NINE COMMERCIAL APPLE PRODUCTION REGIONS}

\begin{tabular}{lc}
\hline Production Region & $\begin{array}{c}\text { Yield Per Acre }^{\mathrm{a}} \\
46-\text { Pound Cartons }\end{array}$ \\
\hline New England & $296^{\mathrm{b}}$ \\
New York & $337^{\mathrm{c}}$ \\
Pennsylvania & $339^{\mathrm{d}}$ \\
West Virginia & $339^{\mathrm{d}}$ \\
Virginia & $339^{\mathrm{d}}$ \\
Michigan & $417^{\mathrm{e}}$ \\
Washington & $431^{\mathrm{f}}$ \\
Oregon & $428^{\mathrm{g}}$ \\
California & $783^{\mathrm{h}}$ \\
\hline
\end{tabular}

${ }^{a}$ All yields were given in bushels and converted to cartons on the basis of 48 pounds equal one bushel and 46 pounds equal one carton.

${ }^{\mathrm{b}}$ Frederick A. Perkins, Organization and Management of 45 Maine Commercial Apple Farms, Agricultural Experiment Station Bulletin 589 (Orono, Maine: University of Maine, 1960) p. 14.

${ }^{\mathrm{C}}$ C. D. Kearl and Darwin P. Snyder, Cash Crops and Fruit Costs and Returns from Farm Cost Accounts, Cornell University Agricultural Experiment Station, A. E. Res. 325 (Ithaca, New York: Cornell University) p. 7.

${ }^{d}$ C. S. Bittner, et. al., The Golden Delicious Apple in Pennsylvania, Agricultural Extension Service Circular 547 (University Park, Pennsylvania: The Pennsylvania State University) p. 6.

${ }^{\mathrm{e}}$ Myron Kelsey, et. al., Economics of Apple Production in Southwestern Michigan, Agricultural Economics Report No. 184 (East Lansing, Michigan: Michigan State University, 1971) pp. 9-10.

${ }^{f}$ C. H. Zuroske, Apple Production Costs and Returns, Washington Agricultural Experiment Station Bulletin 696 (Washington State Univeristy, 1968) p. 3.

${ }^{9}$ Warren J. Green, et. al., The Cost of Producing Apples and Pears in the Hood River Valley, Agricultural Experiment Station Bulletin 573 (Corvallis, Oregon: Oregon State College, 1960) p. 18.

h Burt Burlingame and Edward C. Koch, Apple Production Costs for Santa Cruz County, Agricultural Extension Service, (University of California, 1967) pp. 3-4; 
TABLE 6

\section{MAXIMUM ACREAGE CONSTRAINTS USED IN ALTERNATIVES I, II, AND III}

\begin{tabular}{lccc}
\hline \hline \multirow{2}{*}{$\begin{array}{l}\text { Production } \\
\text { Region }\end{array}$} & \multicolumn{2}{c}{ Maximum Constraint (Acres) } \\
\cline { 2 - 4 } & Alternative I & Alternative II & Alternative III $^{\mathbf{h}}$ \\
\hline New England & $27,979^{\mathrm{a}}$ & 23,818 & 21,436 \\
New York & $74,376^{\mathrm{b}}$ & 30,256 & 27,230 \\
Pennsylvania & $38,558^{\mathrm{c}}$ & 10,256 & 9,230 \\
West Virginia & $19,100^{\mathrm{c}}$ & 9,315 & 8,384 \\
Virginia & $37,206^{\mathrm{C}}$ & 14,157 & 12,741 \\
Michigan & $76,000^{\mathrm{d}}$ & 30,294 & 27,265 \\
Washington & $92,244^{\mathrm{e}}$ & 66,167 & 59,550 \\
Oregon & $7,254^{\mathrm{f}}$ & 5,052 & 4,547 \\
California & $26,120^{\mathrm{g}}$ & 6,094 & 5,485 \\
\hline
\end{tabular}

¿U. S. Department of Agriculture, Statistical Reporting Service, Crop Reporting Board, 1967 Regional Summary of Fruit Tree Surveys, Selected Appalachian States (Washington, 1968) p. 22.

bidid., p. 20.

clbid., p. 5.

${ }^{d} U$. S. Department of Agriculture, Statistical Reporting Service, Crop Reporting Board, 1968 Regional Summary of Fruit Tree Surveys, Selected Central States (Washington), p. 5.

'Letter from Emery Wilcox, Agricultural Statistician in Charge, Statistical Reporting Service, Seattle, Washington, December 13, 1971.

Letter from Leonard Orvold, Agricultural Statistician in Charge, Statistical Reporting Service, Portland, Oregon, December 14, 1971.

${ }^{9}$ California Crop and Livestock Reporting Service, 1970 California Fruit and Nut Acreage (1971), p. 3.

${ }^{\mathrm{h}}$ For method of computation see Appendix Table $\mathrm{E}$.

'Computed by reducing Alternative II acreage constraints by 10 per cent.

acreage constraints in Alternative II were reduced 10 per cent for Alternative III (Table 6).

\section{Transportation}

Improvements in the highway network and rail transportation as well as other technological improvements in the transportation industry could reduce transportation costs. The effect of decreased transportation costs was tested in Alternative IV by reducing all transportation rates 10 per cent. All other data used in Alternative IV are the same as in Alternative II. 


\section{Production Costs}

Alternative $\mathrm{V}$ is the same as Alternative II except that production costs for the production regions on the west coast (Washington, Oregon, and California) were reduced 10 per cent. This was done to account to some degree for the premium prices paid for western-produced apples over those produced in the eastern half of the United States.

\section{Regional Consumption}

Alternative $\mathrm{VI}$ is the same as Alternative $\mathrm{II}$ except that regional consumption was projected to 1985.

Projection of Per Capita Consumption. In order to get an indication of the direction of growth in the fresh apple industry, population and per capita consumption were projected to 1985 . The decreasing rate of decline of the ERS per capita fresh apple consumption estimates from 1909 to 1969 (Appendix Table F) suggests the use of a logarithmic transformation on the consumption data before fitting a linear trend equation. Therefore the per capita fresh apple consumption for these years was transformed to natural logs and the following linear regression was fitted to these transformations:

$$
y=a+b x+\epsilon
$$

where the $y$ value is the natural log of the ERS consumption estimate, the $x$ value corresponds to the last two digits of the year, and $\epsilon$ is the error term. The resulting regression equation is:

$$
\hat{y}=4.49932692-.02664828(x)
$$

and the corresponding $\mathrm{R}^{2^{8}}$ is .93 . This equation was used to predict the consumption value for 1985 , which is:

$$
\begin{gathered}
\hat{y}=4.49932692-.02664828(85) \\
=2.23422318
\end{gathered}
$$

Thus, the United States per capita fresh apple consumption estimate for 1985 is equivalent to the antilog of 2.23422318 which is 9.3 pounds. It should be noted that this projection was for several years from the last date in the regression equation, and therefore, it should be used with some reservation.

The ERS per capita fresh apple consumption estimate was adjusted for regional differences according to the method described in the Basic Model. The resulting consumption estimates for 1985 by ARS regions are:
Northeast
9.7 pounds
North Central 10.2 pounds
West
10.0 pounds
South
8.0 pounds

Projections of Regional Consumption. Bureau of the Census population estimates by states for 1985 were used for regional population estimates (Appendix Table G). Calculated population for each region was multiplied by

${ }^{8}$ The percentage of variability in $y$ (consumption) due to the linear relationship of $x$ (years). 
the appropriate regional per capita consumption estimate to arrive at estimated regional fresh apple consumption for 1985 . This is expressed in 46-pound carton units in Table 7.

TABLE 7

ESTIMATED REGIONAL FRESH APPLE CONSUMPTION FOR 1985

\begin{tabular}{|c|c|}
\hline $\begin{array}{l}\text { Consumption } \\
\text { Region }\end{array}$ & \multirow{2}{*}{$\begin{array}{c}\begin{array}{c}\text { Estimated Regional } \\
\text { Consumption } \\
\text { (cartons) }\end{array} \\
\text { (ten thousands) }\end{array}$} \\
\hline & \\
\hline 1 New England & 280.0 \\
\hline $2 N Y$ & 451.6 \\
\hline 3 PA & 259.2 \\
\hline $4 \mathrm{NJ}$ & 190.9 \\
\hline 5 DE-MD & 96.9 \\
\hline $6 \mathrm{WV}$ & 29.0 \\
\hline 7 VA & 97.7 \\
\hline 8 NC-SC-GA & 246.0 \\
\hline $9 \mathrm{FL}$ & 167.8 \\
\hline $10 \mathrm{MI}$ & 215.7 \\
\hline 11 WI-IL-IN & 516.6 \\
\hline $12 \mathrm{OH}$ & 274.2 \\
\hline $13 \mathrm{KY}-\mathrm{TN}$ & 137.2 \\
\hline 14 AR-LA-MS-AL & 234.5 \\
\hline 15 ND-SD-MN & 122.9 \\
\hline 16 NE-IA-KS-MO & 261.9 \\
\hline 17 OK-TX & 279.6 \\
\hline $18 \mathrm{MT}-I \mathrm{D}-\mathrm{WY}$ & 43.7 \\
\hline 19 NV-UT-CO-AZ-NM & 187.9 \\
\hline 20 WA & 78.4 \\
\hline $21 \mathrm{OR}$ & 51.7 \\
\hline $22 \mathrm{CA}$ & 630.4 \\
\hline TOTAL & $4,853.8$ \\
\hline
\end{tabular}

${ }^{a}$ Computed by multiplying estimated regional population (Appendix Table G) by the appropriate per capita consumption estimate (p. 18) and dividing by 46 . 


\section{MODEL RESULTS}

\section{Basic Model}

In the Basic Model fresh apple production in each production region was limited by the amount of total cropland in that region. Thus it was possible that any region could have all of its cropland allocated to fresh apple production. The value of such a model is that regional fresh apple production is determined on the basis of production costs and transportation rates-the acreage constraint is so large that it is not a limiting factor.

The analysis using the assumptions of the Basic Model showed all regions with excess acreages not used for fresh apple production. The three regions with the highest production costs per unit of output-New England, Washington, and Oregon-did not produce fresh apples (Table 8).

Figure 3 shows the spatial flow pattern which minimized total transportation and production costs in the Basic Model. The numbers on the arrows indicate the number of cartons in tens of thousands being shipped to each consumption region. Underscored numbers indicate production consumed within the production region. The principal direction of shipments in this solution was from east to west. With the limitations imposed, California was the only fresh apple producer on the West Coast, and it supplied regions 19, 20, 21, and 22.

\section{TABLE 8}

\section{LEAST-COST FRESH APPLE PRODUCTION BY REGION FOR THE BASIC MODEL}

\begin{tabular}{lccc}
\hline $\begin{array}{l}\text { Production } \\
\text { Region }\end{array}$ & $\begin{array}{c}\text { Acreage in Fresh } \\
\text { Apple Production }\end{array}$ & $\begin{array}{c}\text { Unused } \\
\text { Acreage }^{\mathbf{a}}\end{array}$ & $\begin{array}{c}\text { Total } \\
\text { Production } \\
\text { (cartons) }\end{array}$ \\
\hline New England & 0 & $3,584,000$ & $\begin{array}{c}\text { (ten thousands) } \\
\text { New York }\end{array}$ \\
Pennsylvania & 30,022 & $8,897,978$ & 0 \\
West Virginia & 29,727 & $7,803,273$ & $1,011.7$ \\
Virginia & 25,100 & $2,817,900$ & $1,007.7$ \\
Michigan & 36,554 & $6,611,446$ & 850.8 \\
Washington & 32,914 & $10,411,086$ & $1,239.1$ \\
Oregon & 0 & $14,926,000$ & $1,372.5$ \\
California & 0 & $17,002,000$ & 0 \\
TOTALS & 13,487 & $32,277,513$ & 0 \\
\hline
\end{tabular}

\footnotetext{
${ }^{\mathrm{a}}$ Rounded to the nearest whole number.

${ }^{b}$ Rounded to the nearest tenth.
} 


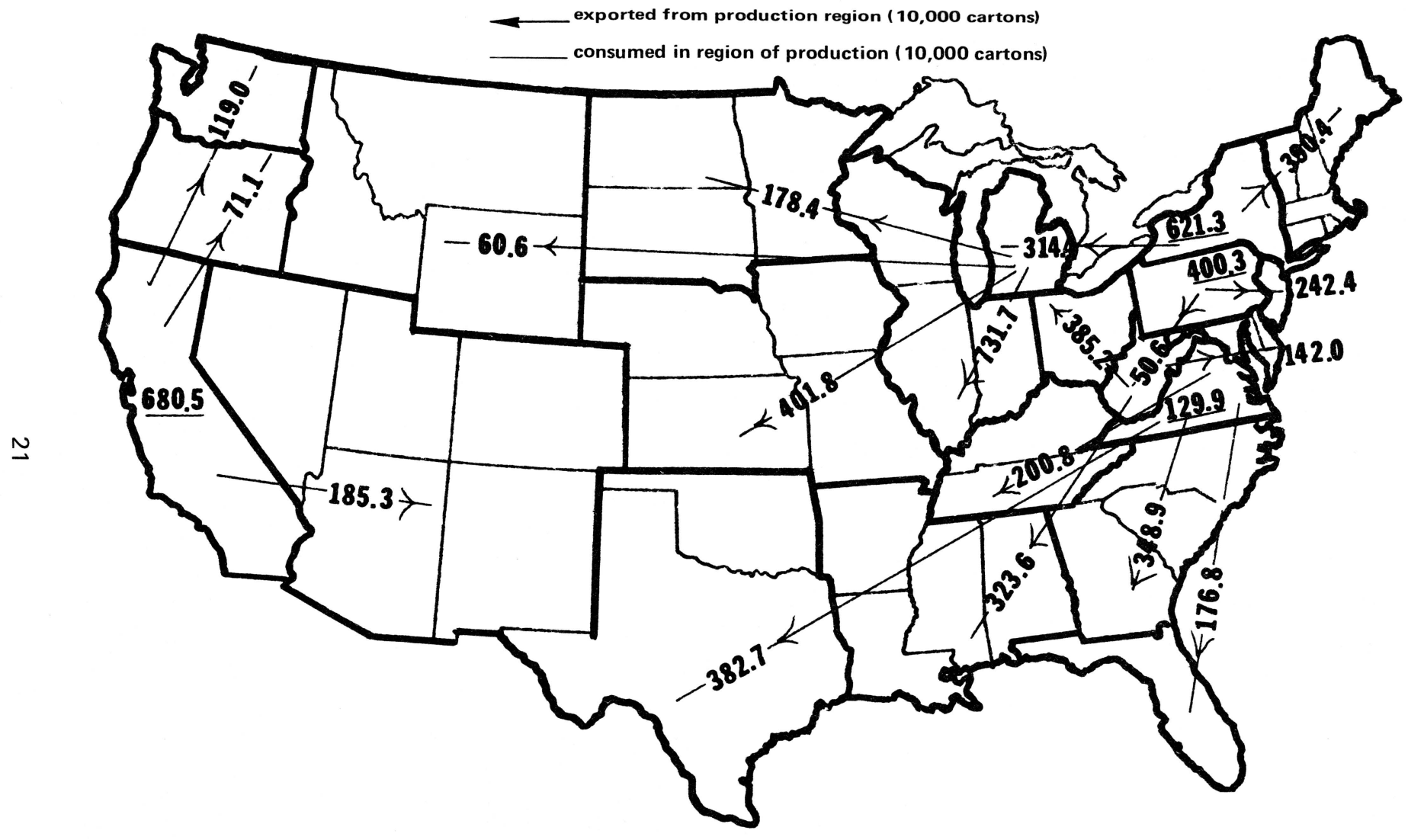

Figure 3. Least-cost Flow Pattern for the Basic Model 
In this initial solution Virginia had the largest number of acres in fresh apple production $(36,554$ acres); however, due to higher yields, Michigan led in production. The aggregate cost of production and transportation in the Basic Model was \$121.8 million (Appendix Table $\mathrm{H}$ ).

This solution for the Basic Model was quite unlike conditions in the fresh apple industry today. In actuality Washington is an important supplier of fresh apples in the United States and makes shipments as far away as New York and Florida. California is a deficit region, relying on Washington and Oregon for a portion of the fresh apples consumed in the state. Therefore, subsequent assumptions were made in the Basic Model in order to arrive at a more realistic solution.

\section{Alternative I}

The maximum acreage constraint in Alternative I was the acreage devoted to apple production as reported in surveys between 1968 and 1970 . Thus only the land in each region used for apple production recently, including apples for processing, was included in this alternative.

The solution to Alternative I was very similar to that of the Basic Model. There was no change in the direction of flow or the regions engaged in fresh apple production (Table 9, Figure 4). In West Virginia, acreage in fresh apple production was reduced from 25,100 acres in the Basic Model to the maximum acreage constraint of 19,100 for Alternative I. This reduction in the fresh apple supply was compensated for by increased production in Virginia and Pennsylvania. The $\$ 20$ thousand increase in aggregate costs ${ }^{9}$ over the Basic Model was the result of increased transportation costs, since West Virginia, Virginia, and Pennsylvania all have the same production costs.

The solution to Alternative I, like the Basic Model solution, did not reflect present conditions in the fresh apple industry. This could be due to various factors, e.g., inaccurate cost or other data used in the model or an actual situation of inefficient allocations of the fresh apple supplies. Since all land used for apple production will not always bear fruit which will be offered for sale on the fresh market, an attempt was made to estimate acreage suitable for the fresh market.

\section{Alternative II}

Acreage restrictions in this alternative were arrived at by multiplying the per cent of total apple production consumed fresh by total acreage devoted to apple production for each production region. The resulting flow pattern was predominately west to east with almost all eastward shipments originating in Washington (Figure 5). Washington also was the leading production region in terms of acreage and output (Table 10). California changed from a surplus region

${ }^{9}$ Due to rounding, differences of this magnitude are not apparent in Appendix Table $\mathrm{H}$. 
LEAST-COST FRESH APPLE PRODUCTION BY REGION FOR ALTERNATIVE I

\begin{tabular}{lccc}
\hline $\begin{array}{l}\text { Production } \\
\text { Region }\end{array}$ & $\begin{array}{c}\text { Acreage in Fresh } \\
\text { Apple Production }\end{array}$ & $\begin{array}{c}\text { Unused } \\
\text { Acreage }^{\text {a }}\end{array}$ & $\begin{array}{c}\text { Total } \\
\text { Production } \\
\text { (cartons) }\end{array}$ \\
\hline New England & 0 & & (ten thousands) \\
New York & 30,022 & 27,979 & 0 \\
Pennsylvania & 35,074 & 44,354 & $1,011.7$ \\
West Virginia & 19,100 & 3,484 & $1,189.0$ \\
Virginia & 37,206 & 0 & 647.5 \\
Michigan & 32,914 & 0 & $1,261.2$ \\
Washington & 0 & 43,086 & $1,372.5$ \\
Oregon & 0 & 92,244 & 0 \\
California & 13,487 & 7,254 & 0 \\
TOTALS & 167,803 & 12,633 & $1,056.0$ \\
\hline
\end{tabular}

\footnotetext{
${ }^{\mathrm{a}}$ Rounded to the nearest whole number.

${ }^{b}$ Rounded to the nearest tenth.
}

in Alternative $I$ to a deficit region in Alternative II. Oregon was the only production region which did not produce at all. Of the remaining eight production regions only Washington had surplus acreage. The aggregate cost for Alternative II was $\$ 148.8$ million (Appendix Table H).

In this solution both Pennsylvania and West Virginia shipped apples to other consumption regions but they did not supply consumption needs within their own regions. This probably was due to the location of the points representing production and consumption in each region. In West Virginia, for example, it appears to be more expensive to ship fresh apples from Berkeley Springs, which is in the eastern panhandle, to Charleston than it is to ship apples from State College, Pennsylvania, to Charleston. This seems reasonable, taking into account the difficulty of travel between Berkeley Springs and Charleston due to the topography and highway system. The solution to Alternative II represents the current west-to-east flow pattern in the fresh apple industry with easternproduced apples being consumed east of the Mississippi. Thus it appears that, given the present level of fresh apple production in each commercial production region, the supply is being distributed efficiently. Because the solution to Alternative II was similar to conditions in the apple industry today, it was used as a basis for comparison with the remaining alternatives. 
- exported from production region (10,000 cartons)

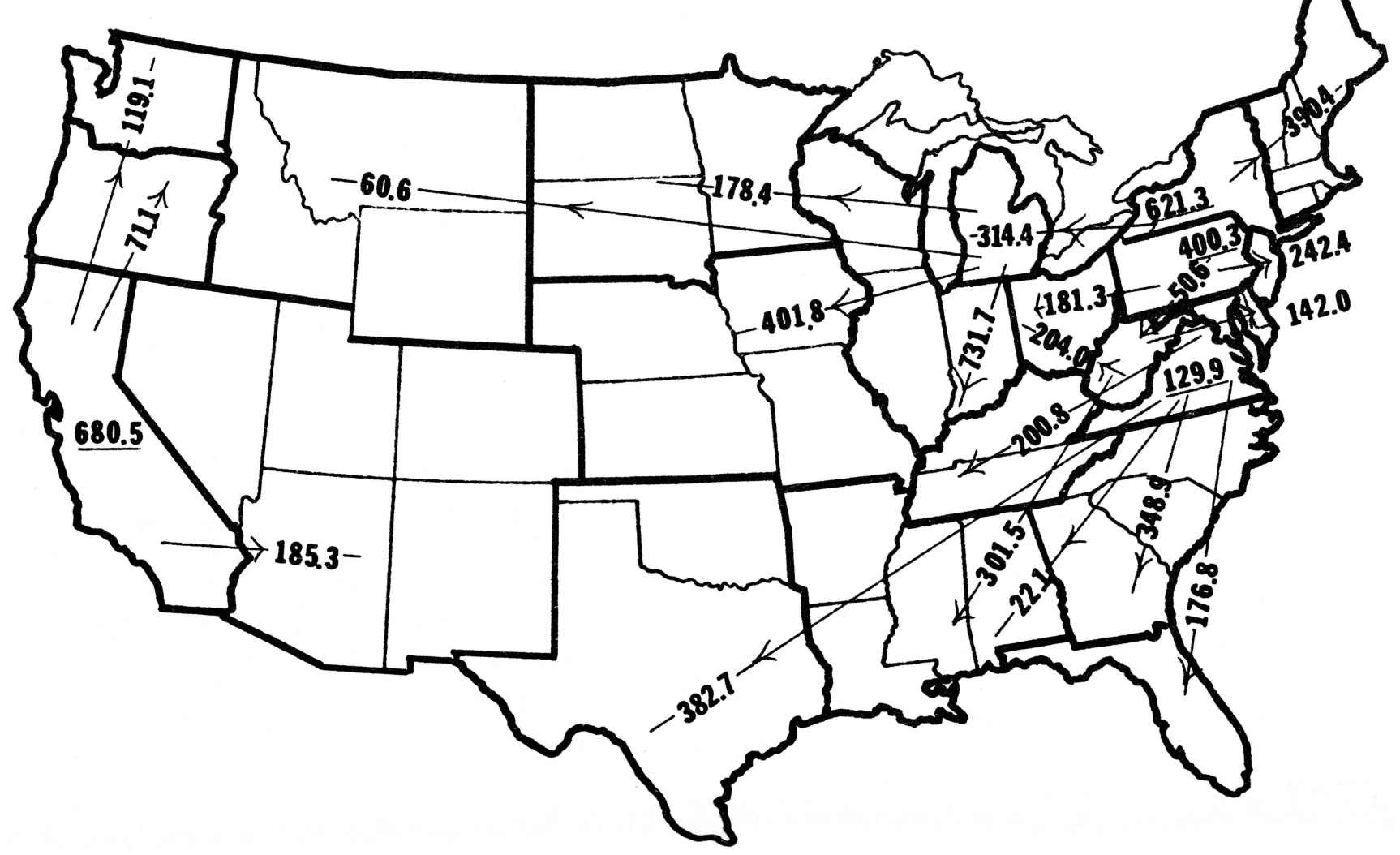

Figure 4. Least-cost Flow Pattern for Alternative I 


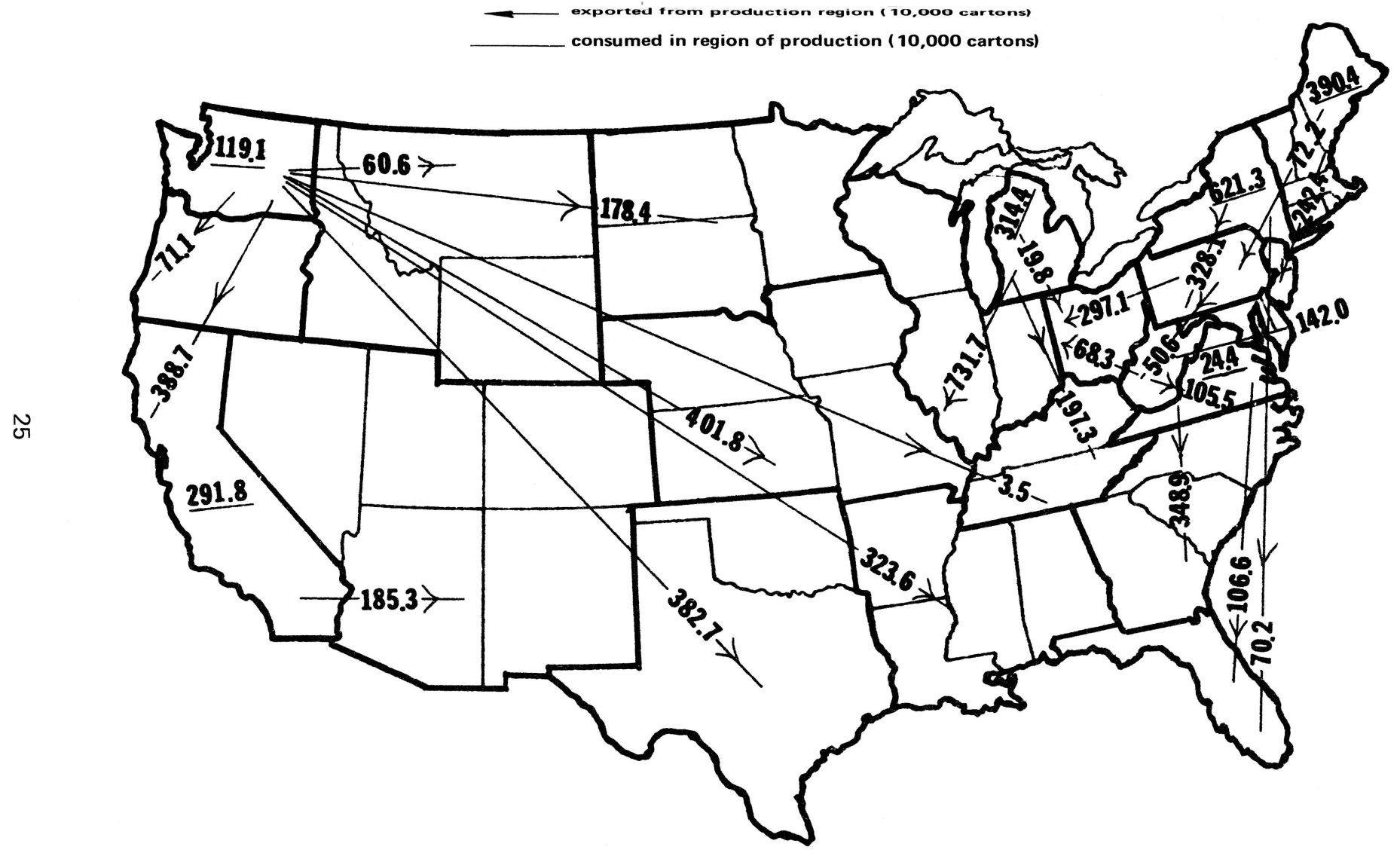

Figure 5. Least-cost Flow Pattern for Alternative II 


\section{LEAST-COST FRESH APPLE PRODUCTION BY REGION FOR ALTERNATIVE II}

\begin{tabular}{lccc}
\hline $\begin{array}{l}\text { Production } \\
\text { Region }\end{array}$ & $\begin{array}{l}\text { Acreage in Fresh } \\
\text { Apple Production }\end{array}$ & $\begin{array}{c}\text { Unused } \\
\text { Acreage }\end{array}$ & $\begin{array}{c}\text { Total } \\
\text { Production }\end{array}$ \\
\hline (cartons)
\end{tabular}

\footnotetext{
${ }^{\mathrm{a}}$ Rounded to the nearest whole number.

${ }^{b}$ Rounded to the nearest tenth.
}

\section{Alternative III}

Statistical reports indicate that total cropland as well as acres planted in apples have been decreasing for a number of years. In order to study the effects of further declines in acres planted in apples, the maximum acreage constraint in Alternative II was reduced 10 per cent for Alternative III. In Alternative II only Washington and Oregon had excess capacity for fresh apple production (Table 11). Therefore, the loss of production capacity in the seven regions which were utilizing all the acreage available had to be compensated for by increased production in Washington and/or Oregon. Thus, acreage devoted to fresh apple production in Washington increased from 44,771 acres in Alternative II to 55,463 acres in Alternative III. Oregon did not produce fresh apples with either alternative.

There was very little change in the spatial flow pattern (Figure 6). The most notable change was the decreased quantity of apples shipped from Pennsylvania and West Virginia to Ohio, and the reliance of Ohio on Washington for more than half the apples consumed fresh in the state. The aggregate cost for Alternative III was $\$ 6.9$ million greater than that of Alternative II (Appendix Table H).

As fewer acres are devoted to fresh apple production, seemingly Washington will increase fresh apple production to offset decreased production in the other commercial apple production regions. 


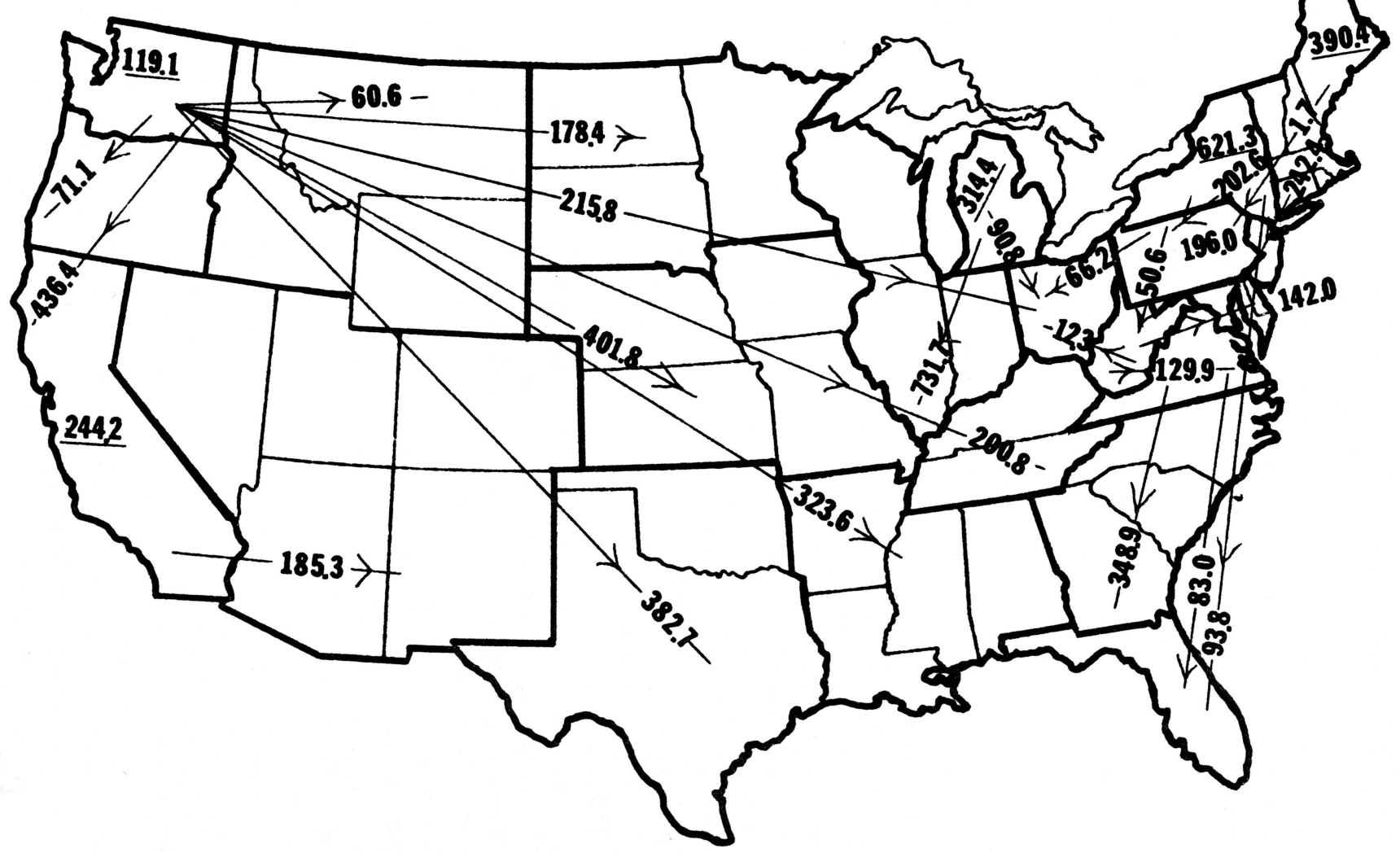

Figure 6. Least-cost Flow Pattern for Alternative III 
LEAST-COST FRESH APPLE PRODUCTION BY REGION FOR ALTERNATIVE III

\begin{tabular}{lccc}
\hline $\begin{array}{l}\text { Production } \\
\text { Region }\end{array}$ & $\begin{array}{c}\text { Acreage in Fresh } \\
\text { Apple Production }\end{array}$ & $\begin{array}{c}\text { Unused } \\
\text { Acreage }^{\mathbf{a}}\end{array}$ & $\begin{array}{c}\text { Total } \\
\text { Production } \\
\text { (cartons) }\end{array}$ \\
\hline New England & 21,436 & & $\begin{array}{c}\text { (ten thousands) } \\
\text { New York }\end{array}$ \\
Pennsylvania & 27,230 & 0 & 634.5 \\
West Virginia & 9,230 & 0 & 917.7 \\
Virginia & 8,384 & 0 & 312.8 \\
Michigan & 12,741 & 0 & 284.2 \\
Washington & 27,265 & 0 & 331.9 \\
Oregon & 55,463 & 4,087 & $1,136.9$ \\
California & 0 & 4,547 & $2,390.3$ \\
TOTALS & 5,485 & 0 & 0 \\
\hline
\end{tabular}

${ }^{\mathrm{a}}$ Rounded to the nearest whole number.

${ }^{b}$ Rounded to the nearest tenth.

\section{Alternative IV}

Costs associated with long distance and transportation restrict interregional competition and increase the location advantage of producers situated near densely populated market areas. Technological improvements which decrease transportation cost simultaneously reduce this location advantage and tend to increase interregional competition. Transportation rates were decreased by 10 per cent for Alternative IV to study the effect of decreased transportation costs on interregional competition. All other data used in this alternative were the same as used in Alternative II.

The decrease in transportation rates did not alter production distribution or affect very significantly the flow pattern of fresh apples (Table 12, Figure 7). In this alternative Pennsylvania and Virginia did consume a larger portion of their production than in Alternative II. Shipments from Virginia to Florida decreased substantially, and shipments from New York to Florida increased. West Virginia apples which were previously shipped to Virginia were shipped to Ohio. A limited quantity of apples which was shipped from Washington to region 13 (Kentucky-Tennessee) in Alternative II was shipped to Ohio in Alternative IV. From this it appears that a small reduction in transportation costs would have very little effect on interregional competition in the fresh apple industry. 


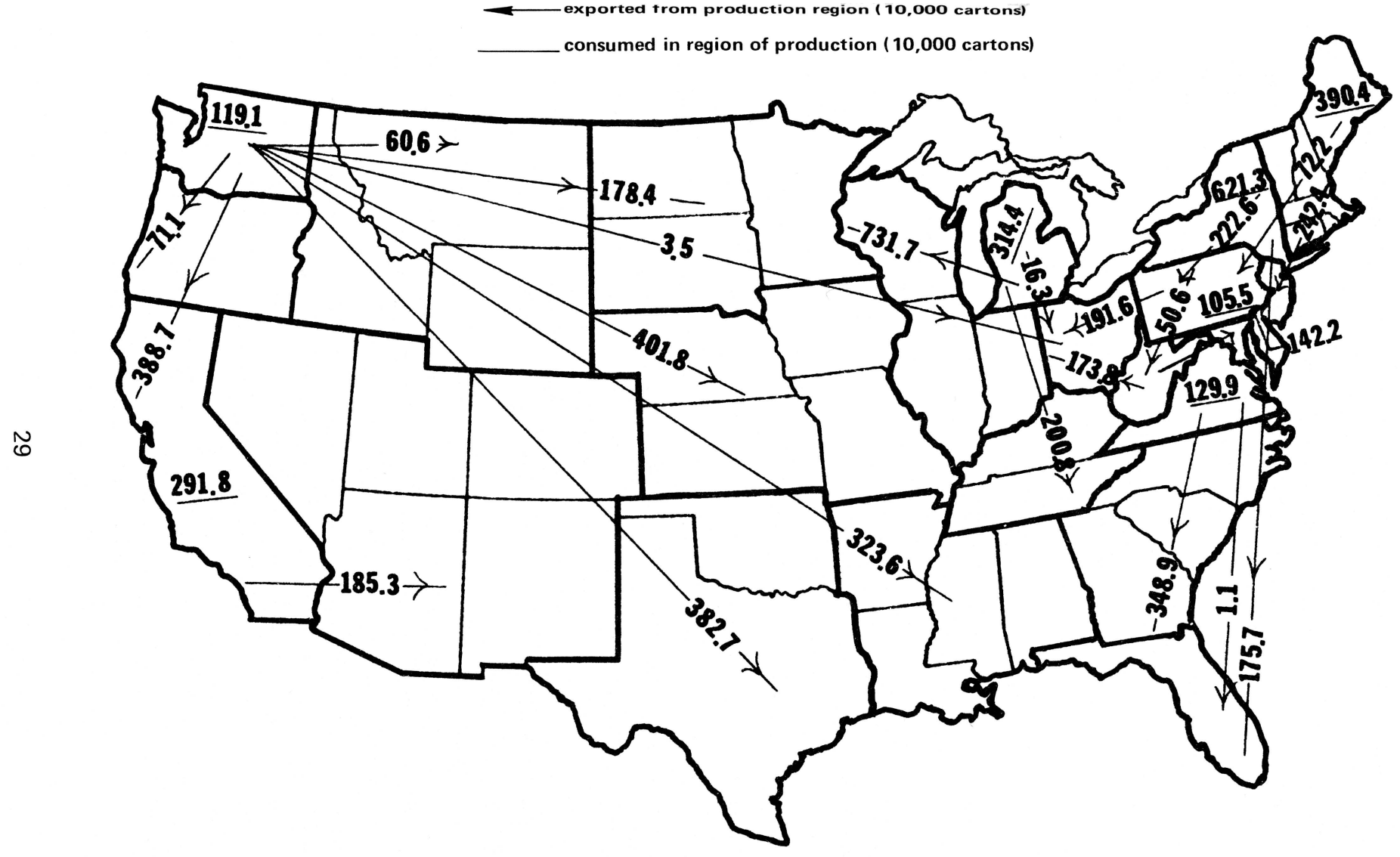

Figure 7. Least-cost Flow Pattern for Alternative IV 


\section{LEAST-COST FRESH APPLE PRODUCTION BY REGION FOR ALTERNATIVE IV}

\begin{tabular}{lccc}
\hline $\begin{array}{l}\text { Production } \\
\text { Region }\end{array}$ & $\begin{array}{c}\text { Acreage in Fresh } \\
\text { Apple Production }\end{array}$ & $\begin{array}{c}\text { Unused } \\
\text { Acreages }^{\mathbf{a}}\end{array}$ & $\begin{array}{c}\text { Total } \\
\text { Production } \\
\text { (cartons) }\end{array}$ \\
\hline New England & 23,818 & & $\begin{array}{c}\text { (ten thousands) } \\
\text { New York }\end{array}$ \\
Pennsylvania & 30,256 & 0 & 705.0 \\
West Virginia & 10,256 & 0 & $1,019.6$ \\
Virginia & 9,315 & 0 & 347.7 \\
Michigan & 14,157 & 0 & 315.8 \\
Washington & 30,294 & 0 & 479.9 \\
Oregon & 44,771 & 21,396 & $1,263.2$ \\
California & 0 & 5,052 & $1,929.5$ \\
TOTALS & 6,094 & 0 & 0 \\
& 168,961 & & $6,537.8$ \\
\hline
\end{tabular}

\footnotetext{
${ }^{a}$ Rounded to the nearest whole number.

${ }^{b}$ Rounded to the nearest tenth.
}

The aggregate cost of Alternative IV was $\$ 145.6$ million, which was $\$ 3.2$ million less than Alternative II (Appendix Table H).

\section{Alternative $\mathbf{V}$}

There is some evidence that Washington receives premium prices for its apples, which may be due to consumer preference, product differentiation, or some other factors.

Although prices were not used in this model, the premium prices enjoyed by any region may be partially accounted for by decreasing production costs accordingly in that region. In Alternative $\mathrm{V}$ the possibility of a price advantage for all western commercial fresh apple producers was explored by decreasing production costs 10 per cent in Washington, Oregon, and California. All other data used in this alternative were the same as those used in Alternative II.

The 10 per cent reduction in production costs in Washington, Oregon, and California did not change the level of production or direction of flow of fresh apples (Table 13, Figure 8). The only difference between the solutions for Alternative II and Alternative $\mathrm{V}$ was a decrease in aggregate cost of $\$ 5.3$ million (Appendix Table $\mathrm{H}$ ). Thus it appears that simulated higher margins in this alternative through a reduction in production costs would not alter the competitive position of the western fresh apple producers. 


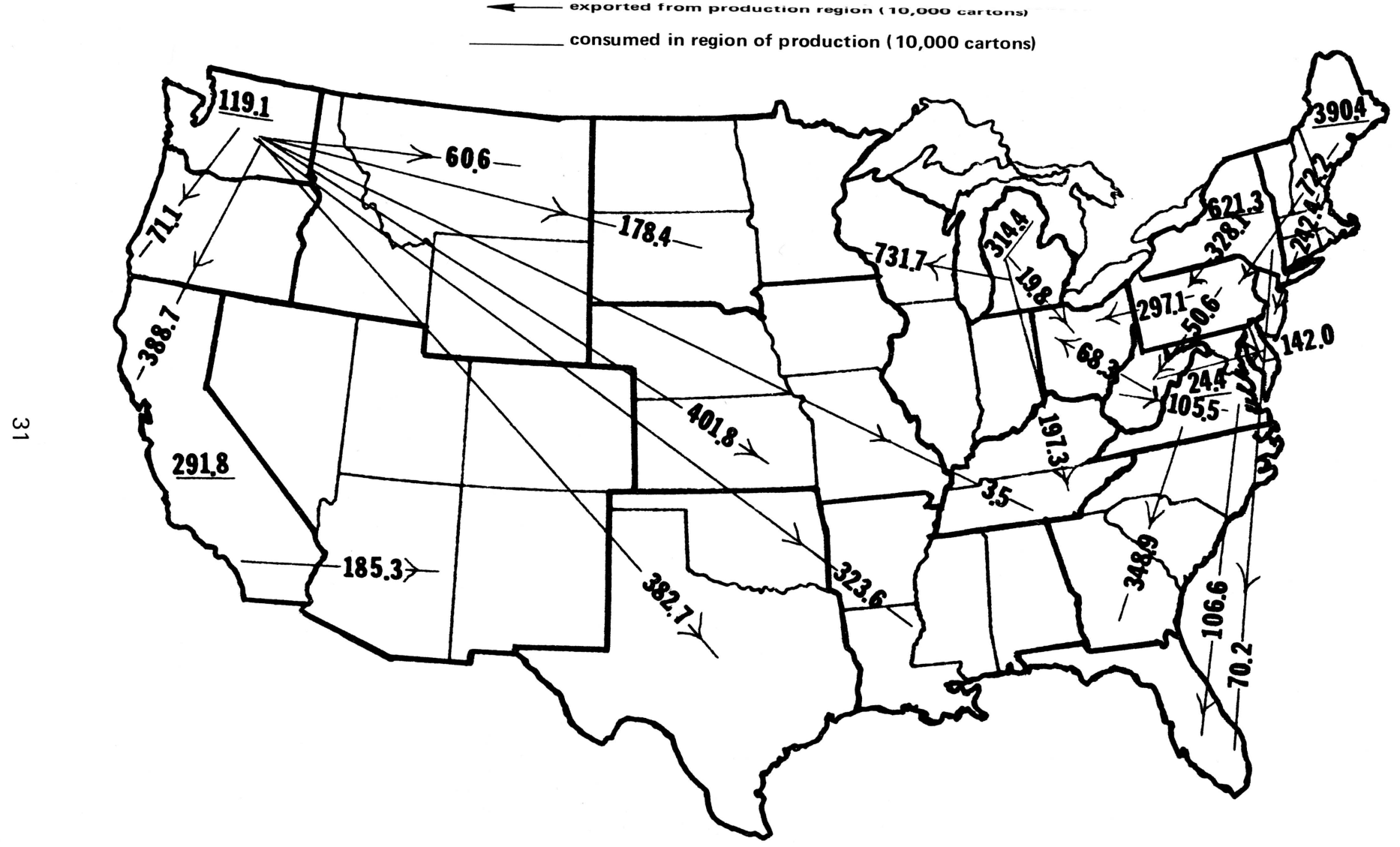

Figure 8. Least-cost Flow Pattern for Alternative V 
LEAST-COST FRESH APPLE PRODUCTION BY REGION FOR ALTERNATIVE V

\begin{tabular}{lccc}
\hline $\begin{array}{l}\text { Production } \\
\text { Region }\end{array}$ & $\begin{array}{c}\text { Acreage in Fresh } \\
\text { Apple Production }\end{array}$ & $\begin{array}{c}\text { Unused } \\
\text { Acreages }^{\mathbf{a}}\end{array}$ & $\begin{array}{c}\text { Total } \\
\text { Production }^{\mathbf{b}} \\
\text { (cartons) }\end{array}$ \\
\hline New England & 23,818 & 0 & $\begin{array}{c}\text { (ten thousands) } \\
\text { New York }\end{array}$ \\
Pennsylvania & 30,256 & 0 & 705.0 \\
West Virginia & 10,256 & 0 & $1,019.6$ \\
Virginia & 9,315 & 0 & 347.7 \\
Michigan & 14,157 & 0 & 315.8 \\
Washington & 30,294 & 0 & 479.9 \\
Oregon & 44,771 & 21,396 & $1,263.2$ \\
California & 0 & 5,052 & $1,929.5$ \\
TOTALS & 6,094 & 0 & 0 \\
\hline
\end{tabular}

${ }^{\mathrm{a}}$ Rounded to the nearest whole number.

${ }^{b}$ Rounded to the nearest tenth.

\section{Alternative VI}

In Alternative $\mathrm{VI}$ regional consumption was projected to 1985 to assess the impact of change in population and growth on the fresh apple industry. The decrease in estimated unadjusted per capita consumption to 9.3 pounds for the United States based on Economic Research Service figures was offset by increased population only in region 19 (Nevada-Utah-Colorado-Arizona-New Mexico), where total consumption would increase by 1.4 per cent. In all other consumption regions, estimated consumption for 1985 was below that of 1969 . The smallest decreases in regional consumption were in Florida and California where estimated consumption decreased by 5.1 and 7.4 per cent, respectively.

The direction of flow in the optimum solution for Alternative $\mathrm{VI}$ was principally east to west (Figure 9). The level of production was the same as for Alternative II for all production regions except New England and Washington, where the levels of production were reduced (Table 14). In this alternative Washington supplied fresh apples to only four consumption regions, including Washington, whereas in Alternative II it supplied nine consumption regions. Shipments of apples from Michigan, the largest producer in Alternative VI, were westward to regions that were supplied by Washington in Alternative II. 


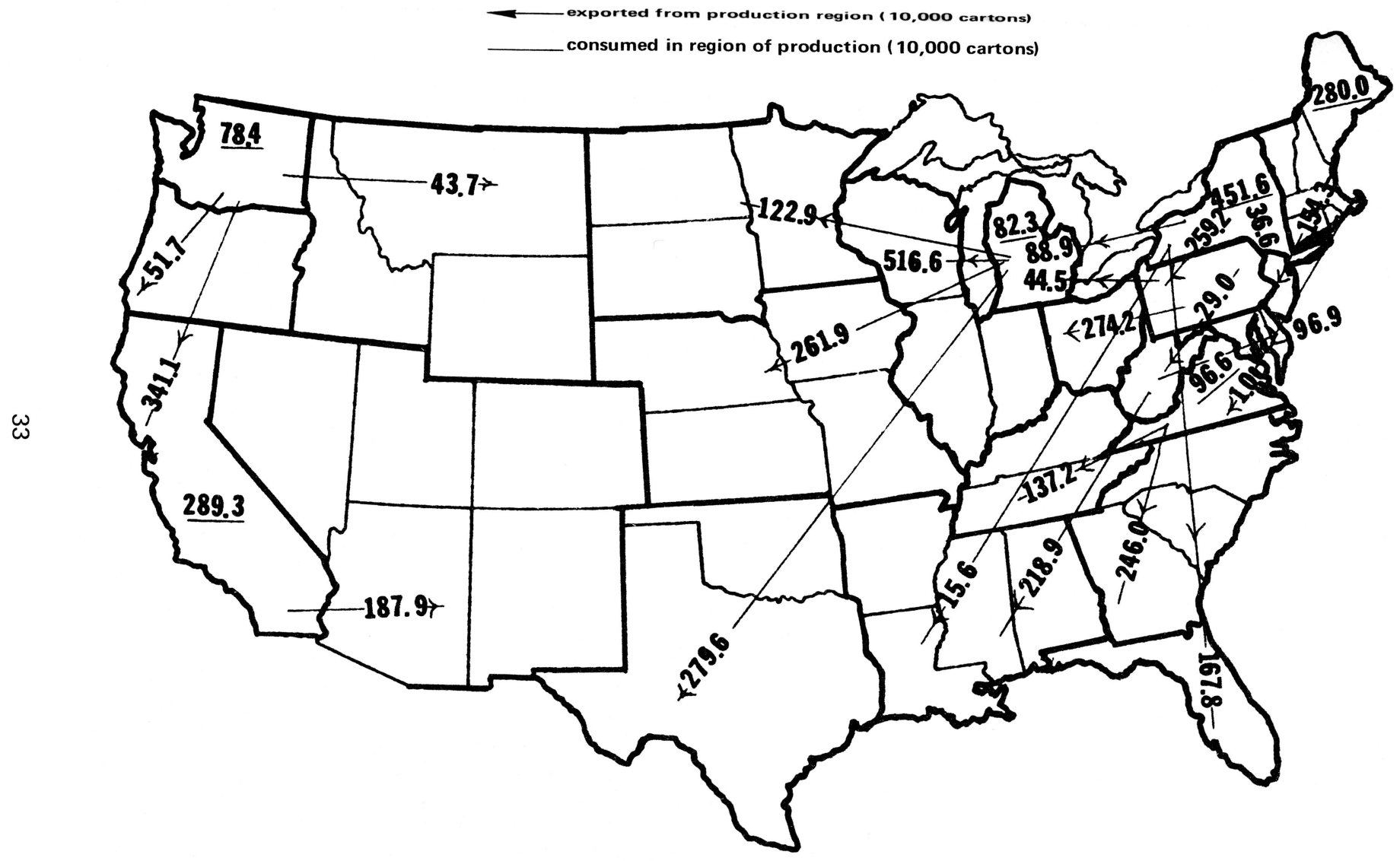

Figure 9. Least-cost Flow Pattern for Alternative VI 


\section{LEAST-COST FRESH APPLE PRODUCTION BY REGION FOR ALTERNATIVE VI}

\begin{tabular}{lccc}
\hline $\begin{array}{l}\text { Production } \\
\text { Region }\end{array}$ & $\begin{array}{l}\text { Acreage in Fresh } \\
\text { Apple Production }\end{array}$ & $\begin{array}{c}\text { Unused } \\
\text { Acreages }^{\mathbf{a}}\end{array}$ & $\begin{array}{c}\text { Total } \\
\text { Production }^{\mathbf{b}} \\
\text { (cartons) }\end{array}$ \\
\hline New England & 14,709 & 9,109 & $\begin{array}{c}\text { (ten thousands) } \\
\text { New York }\end{array}$ \\
Pennsylvania & 30,256 & 0 & 435.3 \\
West Virginia & 10,256 & 0 & $1,019.7$ \\
Virginia & 9,315 & 0 & 347.7 \\
Michigan & 14,157 & 0 & 315.8 \\
Washington & 30,294 & 0 & 479.8 \\
Oregon & 11,946 & 54,221 & $1,263.3$ \\
California & 0 & 5,052 & 514.9 \\
TOTALS & 6,094 & 0 & 0 \\
\hline
\end{tabular}

\footnotetext{
${ }^{a}$ Rounded to the nearest whole number.

${ }^{b}$ Rounded to the nearest tenth.
}

Shipment of Michigan apples westward made it necessary for New York and Pennsylvania fresh apples to be shipped into Michigan to meet its regional consumption needs. Kentucky-Tennessee, which received fresh apples from Washington and Michigan in Alternative $\mathrm{II}$, received its fresh apple supply from Virginia in Alternative VI.

The aggregate production and transportation cost for this solution was $\$ 97.8$ million (Appendix Table $\mathrm{H}$ ). This was the least-cost alternative which could be explained by the fact that as consumption decreased the production capacity remained constant. Therefore, the eastern production regions and Michigan were capable of meeting consumption needs in the eastern half of the United States and could do so at less cost than Washington. The solution to this alternative suggested that a continued decline in aggregate fresh apple consumption would be felt by western fresh apple producers more rapidly than by the producers in the eastern half of the United States.

\section{Shadow Prices}

Shadow prices (see definition with Table 15) on limited acreages give the amount by which the aggregate cost would be reduced if one additional acre of land were brought into fresh apple production. In the Basic Model acreage excesses existed in all regions; therefore, no shadow prices were determined (Table 15). In Alternative I only West Virginia and Virginia produced at the 
TABLE 15

SHADOW PRICES ${ }^{a}$ ON LIMITED ACREAGES BY PRODUCTION REGION FOR THE BASIC MODEL AND SIX ALTERNATIVES ${ }^{b}$

\begin{tabular}{lccccccc}
\hline \hline $\begin{array}{l}\text { Production } \\
\text { Region }\end{array}$ & $\begin{array}{c}\text { Basic } \\
\text { Model }\end{array}$ & $\begin{array}{c}\text { Alternative } \\
\text { I }\end{array}$ & $\begin{array}{c}\text { Alternative } \\
\text { II }\end{array}$ & $\begin{array}{c}\text { Alternative } \\
\text { III }\end{array}$ & $\begin{array}{c}\text { Alternative } \\
\text { IV }\end{array}$ & $\begin{array}{c}\text { Alternative } \\
\text { V }\end{array}$ & $\begin{array}{c}\text { Alternative } \\
\text { VI }\end{array}$ \\
\hline New England & - & - & $\$ 269.61$ & $\$ 284.41$ & $\$ 225.21$ & $\$ 200.37$ & - \\
New York & - & - & 553.07 & 569.92 & 499.15 & 474.24 & $\$ 232.64$ \\
Pennsylvania & - & - & 588.36 & 605.31 & 534.12 & 509.06 & 296.53 \\
West Virginia & - & $\$ 3.39$ & 591.75 & 608.70 & 537.51 & 512.45 & 306.70 \\
Virginia & - & $0^{c}$ & 605.31 & 622.26 & 551.07 & 526.01 & 306.70 \\
Michigan & - & - & 685.92 & 706.77 & 615.03 & 588.37 & 351.97 \\
Washington & - & - & - & - & - & - & - \\
Oregon & - & - & - & - & - & - & - \\
California & - & - & 582.87 & 582.85 & 567.19 & 538.67 & 582.85 \\
\hline
\end{tabular}

${ }^{\mathrm{a}}$ Amount by which aggregate cost would be reduced if one acre of land were available for fresh apple production.

${ }^{b}$ Dash indicates that excess acreage existed, therefore no shadow price was determined.

${ }^{c}$ Alternative optimal solutions exist. 
maximum acreage constraint. Aggregate cost would not have been reduced at all due to the existence of alternate optimal solutions if another acre of land had been available in Virginia. The low shadow price for West Virginia indicated that utilization of more land would make little difference in aggregate costs.

The shadow prices for each production region were similar for Alternative II, III, IV, and V. In all four alternatives it appeared that among those regions with restricted acreage, an additional acre of production in Michigan would decrease aggregate costs by the largest amount, while an additional acre in New England would be least beneficial in decreasing aggregate costs. Total consumption of fresh apples was less in Alternative $\mathrm{VI}$ than in the previous solutions. This alternative also had the least aggregate cost of production and transportation. Therefore, the shadow prices for Alternative VI were considerably less than for Alternatives II, III, IV, and V for all production regions except California. This relatively high shadow price for California in Alternative VI indicated that the competitive position of California in the fresh apple industry might improve if aggregate consumption continues to decrease.

Oregon did not produce at all and Washington had excess acreage in each alternative, implying that these two production regions were at a competitive disadvantage relative to the other production regions in the model.

The shadow prices on the 22 consumption regions give the amount by which the aggregate cost would increase if consumption were increased by one carton in any one consumption region (Table 16). In the Basic Model and Alternative I the shadow prices were similar. Shadow prices in the western consumption regions were the highest, meaning it would be more costly to meet increased consumption in the western regions than elsewhere. Shadow prices were higher in Alternative II than the first two cases. This increase was probably due to scarce acreage in Alternative II, causing regions with higher per unit production costs to enter production.

In Alternative III, where acreage was restricted further, shadow prices increased in those consumption regions which were supplied by production regions east of the Mississippi and remained constant in those consumption regions supplied by Washington and California. The shadow prices remained constant for the latter group because Washington had excess acreage available for fresh apple production whereas the production regions east of the Mississippi were already producing at their maximum acreage constraints.

The decrease in transportation rates of 10 per cent in Alternative IV lowered all shadow prices from those given in Alternative II. This was expected, since all production regions could supply fresh apples at less cost than in Alternative II.

In Alternative $\mathrm{V}$ production costs on the west coast were decreased by 10 per cent. All shadow prices for this alternative were less than those in Alternative II. This was so because any increase in consumption would be supplied by western producers and the decrease in their costs would decrease shadow prices for all consumption regions to which they would ship. 
SHADOW PRICES ${ }^{a}$ ON CONSUMPTION BY CONSUMPTION REGION FOR THE BASIC MODEL AND SIX ALTERNATIVES

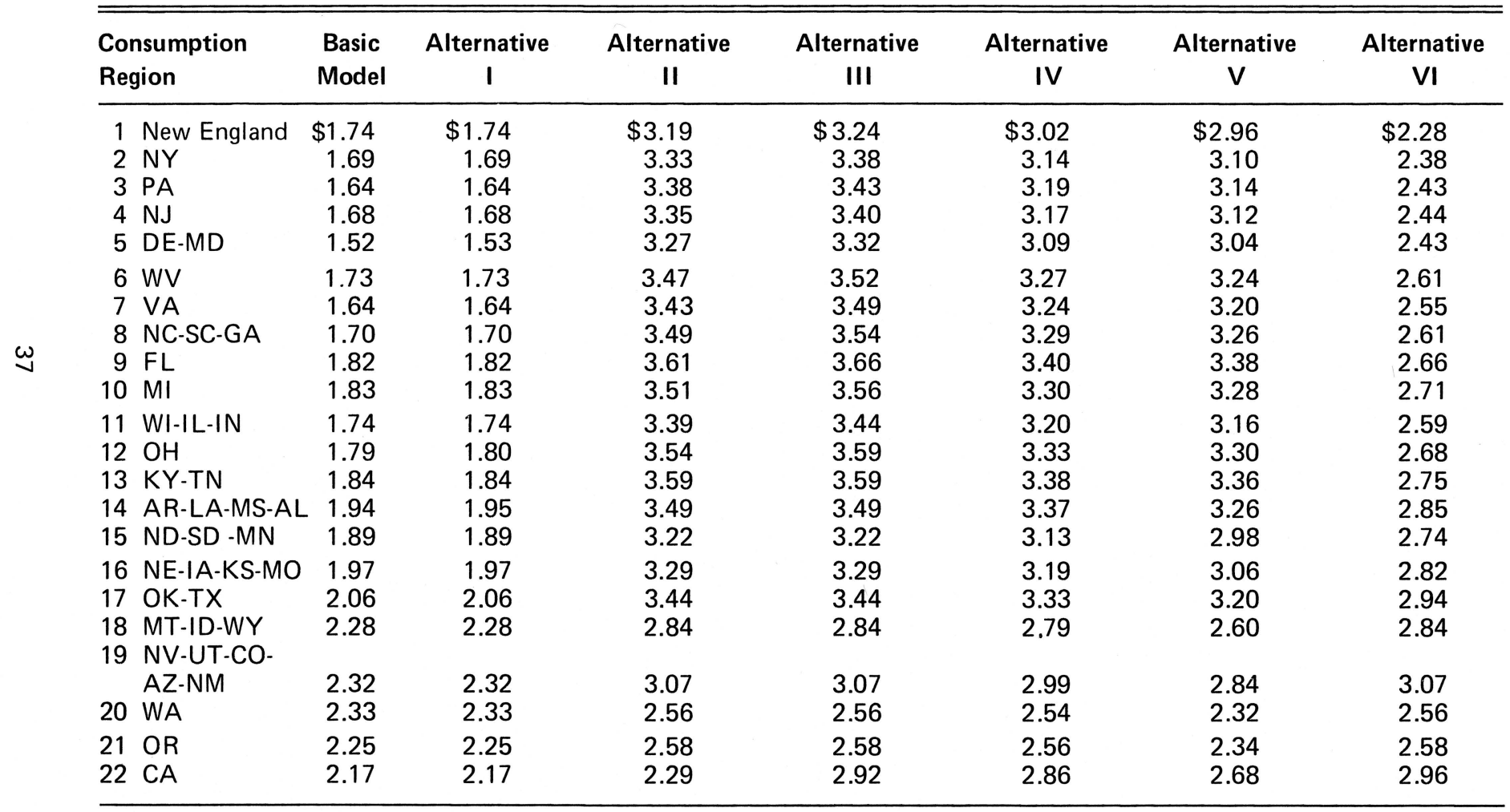

${ }^{\mathrm{a}}$ Amount by which aggregate cost would increase if consumption were increased by one carton in any one consumption region. 
In Alternative VI consumption was projected to 1985. Aggregate consumption was less than in the other alternatives and because of this New England, which had the highest per unit production cost in the eastern half of the United States, had excess acreage. This excess acreage in New England caused all consumption regions which were supplied by eastern producers in Alternative $\mathrm{VI}$ to have lower shadow prices than in Alternative II. Any increase in consumption could be supplied by New England, which had lower per unit production costs than Washington or Oregon. The four consumption regions which were supplied by western producers in Alternative VI had shadow prices equal to those in Alternative II.

\section{Costs of Forced Shipment}

The costs associated with forcing shipment from any production region to any consumption region show the amount by which the aggregate cost would increase with distance of shipment since mileage and transportation costs are positively correlated.

The costs of forcing shipment of West Virginia fresh apples increased from the Basic Model to Alternative I, as West Virginia was one of the two production regions with no excess acreage in Alternative I (Table 17).

Costs of forced shipment were the same in Alternative II and V and generally higher than in the Basic Model and Alternative I due to more restricted maximum acreage constraints. In Alternative III costs of forced shipment were the same as those in Alternative II except for those consumption regions which were supplied by Washington in Alternative III. The costs of forced shipment were higher in those consumption regions, indicating that it would be more difficult for West Virginia to compete with Washington. This was so because acreage in fresh apple production was decreased in West Virginia but increased in Washington.

All costs were lower in Alternative IV than in Alternative II, reflecting the 10 per cent decrease in transportation costs in Alternative IV. In Alternative VI costs of forced shipment from West Virginia were higher than in Alternative II and lower for consumption regions which were supplied by western producers in Alternative II. It appears that in Alternative VI West Virginia was less competitive with the eastern producers-probably due to the availability of excess acreage in New England-and more competitive with the western producers. The decrease in cost of forced shipment to the western regions can be explained partially by the shipment of fresh apples from West Virginia to more distant consumption regions in Alternative $\mathrm{VI}$ than Alternative II; therefore, the increased cost of shipping to the western consumption regions was less than in Alternative II.

The costs of forced shipment from Washington to other consumption regions were very similar for the Basic Model and Alternative I (Table 18). Washington did not produce fresh apples in either case. In Alternatives II and V the costs of forced shipment were the same. These costs were much less than 
COST OF FORCING SHIPMENT OF ONE CARTON OF APPLES FROM WEST VIRGINIA TO ANY CONSUMPTION REGION FOR THE BASIC MODEL AND SIX ALTERNATIVES ${ }^{a}$

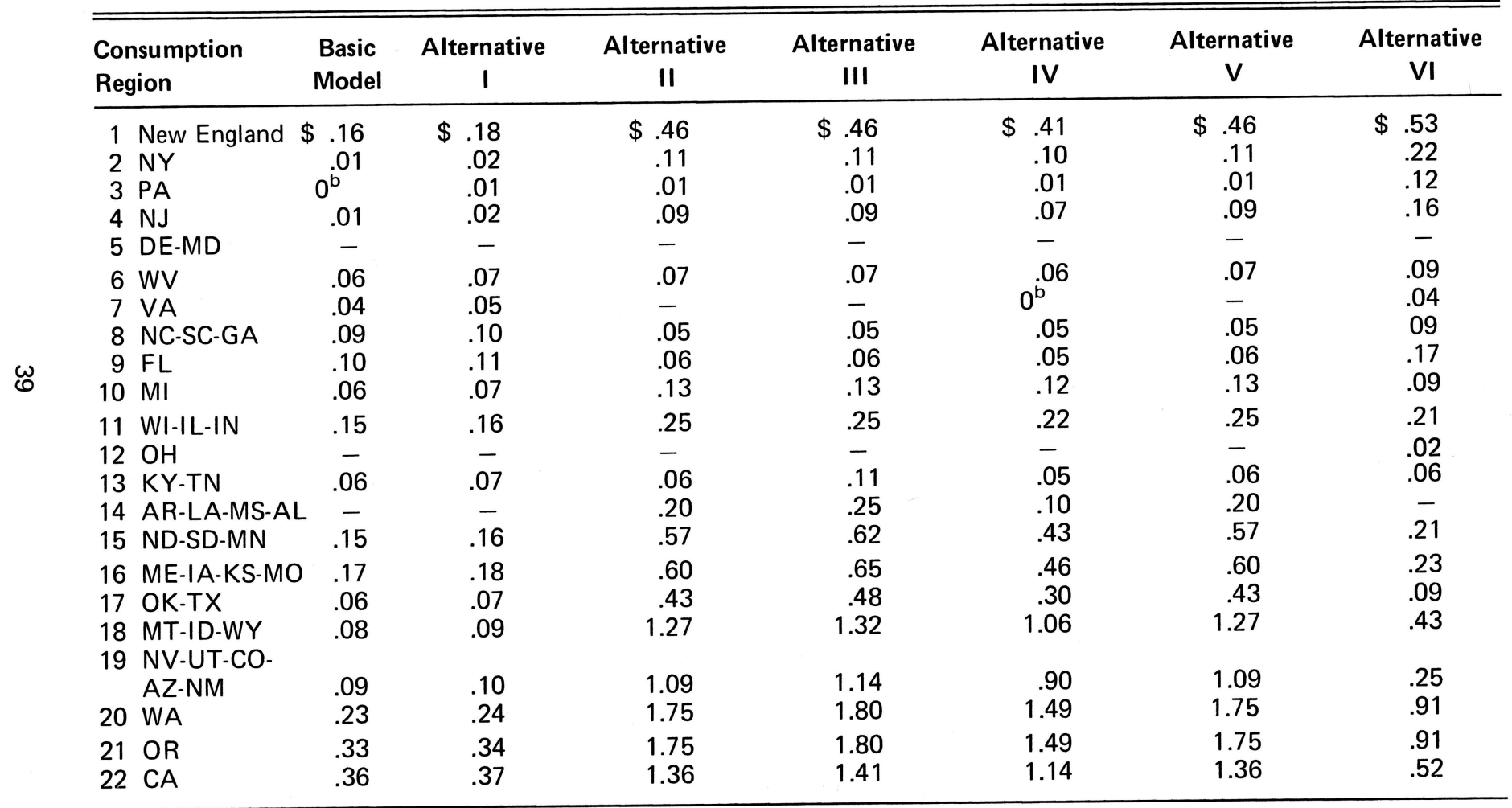

${ }^{\mathrm{a}}$ Dash indicates variables in the basis: costs are given only for nonbasis variables.

${ }^{b}$ Alternate optimal solutions exist. 
TABLE 18

COST OF FORCING SHIPMENT OF ONE CARTON OF APPLES FROM WASHINGTON TO ANY CONSUMPTION REGION FOR THE BASIC MODEL AND SIX ALTERNATIVES ${ }^{a}$

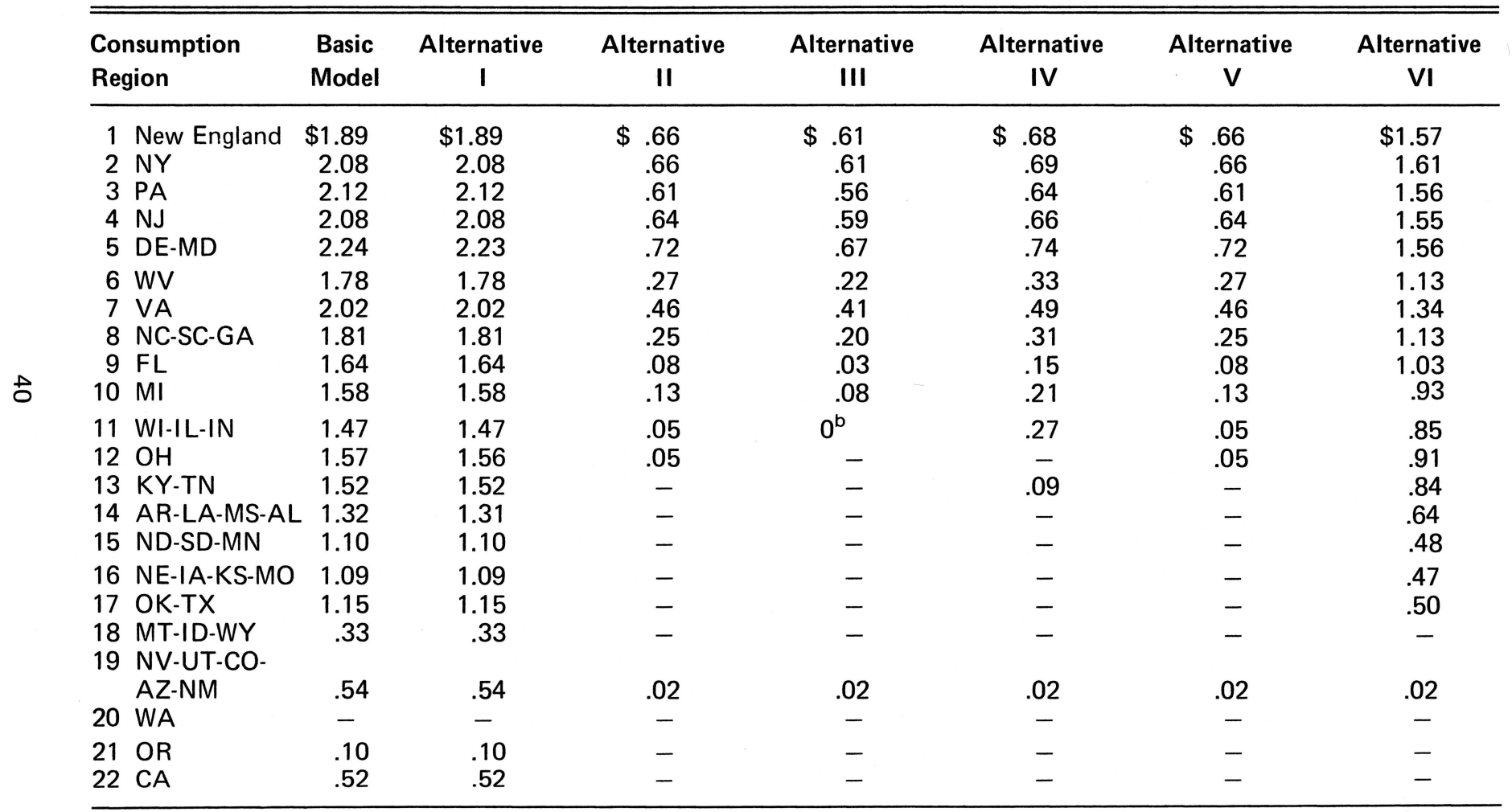

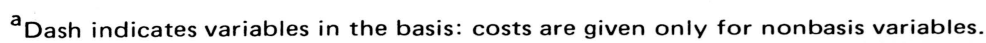

b Alternate optimal solutions exist. 
costs in the first two solutions because Washington was producing heavily in Alternative II and $\mathrm{V}$ and any increase in consumption would have been supplied by Washington. In Alternative III, due to a decrease in the maximum acreage constraints in all production regions, Washington produced more apples than previously and the costs of forced shipment decreased from those of Alternative II.

The costs of forced shipment from Washington increased in Alternative IV, which analyzed the effect of a 10 per cent decrease in all transportation costs. It appears that if transportation costs decrease Washington will become less competitive with the eastern producers. In Alternative $\mathrm{VI}$, where consumption was projected to 1985, the costs of forced shipment from Washington were higher than in Alternative II. As aggregate consumption decreased, Washington with its comparatively high per unit production costs, was not able to compete with the eastern producers. Washington fresh apple production in Alternative $\mathrm{VI}$ was less than half that of Alternative II.

\section{CONCLUSIONS AND IMPLICATIONS}

In the solution to the Basic Model where acreage constraints were so large they were not a limiting factor, Washington, which is presently the largest commercial apple producing state, did not produce at all. In order to arrive at a solution which reflected present conditions in the fresh apple industry (Alternative II) acreage in all production regions was restricted so that Washington was forced into production to help meet aggregate consumption needs. Adjustments for the premium price paid for certain varieties of Washington-produced apples did not improve the competitive position of Washington relative to the other commercial apple production regions within the adjustment limits used.

The results indicate that efficiency in the fresh apple industry is not optimal. However, Alternative II indicated that, given the present level of fresh apple production in each commercial region, the supply is being distributed relatively efficiently. If the regional level of production were changed in the direction of the Basic Model solution, total cost would be reduced. This alternative would involve a decrease in fresh apple production in Washington, Oregon, and New England, and an increase in fresh apple production in all the other regions.

There has been a general trend for per unit production costs to increase in Washington, and a recent study indicated that returns did not cover costs in 1965. Apple production in Oregon has decreased over the last 50 years, but pear production has increased substantially. While apples are important contributors to the New England economy, recent increases in peach plantings may signal a gradual shift of emphasis in that region. These trends suggest that fresh apple producers in Washington, Oregon, and New England might be considering downward adjustment of production. 
Shadow prices indicate that additional acreage in Michigan would be most valuable in reducing aggregate costs. Additional production in Michigan could be used to supply the prairie states at less cost than at present with Washington supplying these states. The high shadow price for an additional acre in California in Alternative VI implies that California has the economic potential to become important in the fresh apple industry. But, due to a climate more favorable for production to match the increasing consumption of citrus fruits, it is doubtful that fresh apple production will increase significantly in that state.

Costs of production seem to be more important than transportation rates in determining the optimal location of fresh apple production. High per unit production costs appeared directly related to unused acreage.

Adjustments made in the fresh apple supply in one region affect producers in all other regions. At a time when supply seems to be increasing more rapidly than demand, the results of this study indicate that West Virginia is in a good competitive position to maintain its share of the fresh apple market.

Although this study assumed that apples are a homogeneous product, statistical reports indicate that consumers differentiate between Washington apples and those grown elsewhere. This consumer preference may allow Washington to enjoy premium prices and higher levels of production than would exist under purely competitive conditions. In cases where decreasing consumption necessitates downward production adjustments, such adjustments would more likely take place in production regions other than Washington if consumers continue to differentiate between Washington-grown apples and those produced in other regions.

\section{REFERENCES}

Ben-David, Shaul and Forker, Alan D. Toward the Year 1985; Interregional Competition in Dairy and Vegetable Production. Special Cornell Series No. 9. New York State College of Agriculture at Cornell University.

Bittner, C. S., et. al. The Golden Delicious Apple In Pennsylvania. Agricultural

Extension Service Circular 547. University Park, Pennsylvania: The Pennsylvania State University.

Buchholz, H. E. and Judge, G. G. An Interregional Analysis of the Livestock Economy. University of Illinois Agricultural Economics Research Report No. 75. University of Illinois, 1965.

Bureau of the Census. Revised Projections of the Population of States 1970 to 1985. Washington: U. S. Government Printing Office, 1967.

Burlingame, Burt and Koch, Edward C. Apple Production Costs for Santa Cruz County. Agricultural Extension Service, University of California, 1967.

Cain, Jarvis L. and Toensmeyer, Ulrich C. Interregional Competition in Maryland Produced, Fresh Market Tomatoes. College Park, Maryland: University of Maryland, 1969. 
California Crop and Livestock Reporting Service. 1970 California Fruit and Nut Acreage. Statistical Reporting Service, U. S. Department of Agriculture. Sacramento, California: 1971.

Green, Warren J., et. al. The Cost of Producing Apples and Pears in the Hood River Valley. Agricultural Experiment Station Bulletin 573. Corvallis, Oregon: Oregon State College, 1960.

Havlicek, J., Rizek, R. L. and Judge, G. G. Spatial Structure of the Livestock Industry: Spatial Analyses of the Flows of Slaughter Livestock in 1955 and 1960. North Central Regional Research Bulletin No. 159. Brookings, South Dakota: South Dakota State University, 1964.

Heady, Earl O. and Chandler, Wilfred. Linear Programming Methods. Ames, lowa: The lowa State University Press, 1958.

Heady, Earl O. and Skold, Melvin. Projections of U. S. Agricultural Capacity and Interregional Adjustments in Production and Land Use With Spatial Programming Models. Agricultural and Home Economics Experiment Station Research Bulletin No. 539. Ames, lowa: lowa State University, 1965.

Heady, Earl O. and Whittlesey, Norman K. A Programming Analysis of Interregional Competition and Surplus Capacity of American Agriculture. Agricultural and Home Economics Experiment Station Research Bulletin No. 538. Ames, lowa: lowa State University, 1965.

Household Goods Carriers Bureau. Mileage Guide No. 9. (Washington, 1967).

Judge, George G. Competitive Position of the Connecticut Poultry Industry: A Spatial Equilibrium Model for Eggs. Storrs Agricultural Experiment Station Bulletin 318. Storrs, Connecticut: University of Connecticut, 1965.

Judge, G. G., Havlicek, J. and Rizek, R. L. Spatial Structure of the Livestock Economy: Spatial Analyses of the Meat Marketing Sector in 1955 and 1960. North Central Regional Research Bulletin No. 157. Brookings, South Dakota: South Dakota State University, 1964.

Kearl, C. D. and Snyder, Darwin P. Cash Crops and Fruit Costs and Returns from Farm Cost Accounts. A. E. Res. 325. Ithaca, New York: Cornell University.

Kelsey, Myron, et. al. Economics of Apple Production in Southwestern Michigan. Agricultural Economics Report No. 184. East Lansing, Michigan: Michigan State University, 1971.

Perkins, Frederick A. Organization and Management of 45 Maine Commercial Apple Farms. Agricultural Experiment Station Bulletin 589. Orono, Maine: University of Maine, 1960.

Rizek, R. L., Judge G. G. and Havlicek, J. Spatial Structure of the Livestock Economy: Joint Spatial Analysis of Regional Slaughter and the Flows and 
Pricing of Livestock and Meat. North Central Regional Research Bulletin No. 163. Brookings, South Dakota: South Dakota State University, 1965.

Samuelson, Paul A. "Spatial Price Equilibrium and Linear Programming", American Economic Review, Vol. 42 (1952), 283-303.

Seale, A. D., Jr. Equilibrium Prices and Flows of Broilers in the United States for 1961-63 and 1970. Mississippi Agricultural Experiment Station Bulletin 709. State College, Mississippi: Mississippi State University, 1965.

Takayama, T. and Judge, G. G. "An Interregional Activity Analysis Model for the Agricultural Sector", Journal of Farm Economics, XLVI (1964), 349-365.

United States Department of Agriculture. Agricultural Prices, 1970 Annual Summary. Statistical Reporting Service, Crop Reporting Board, U. S. Department of Agriculture. Washington: U. S. Government Printing Office, 1971.

Agricultural Statistics, 1960. Washington: U. S. Government Printing Office, 1960.

Agricultural Statistics, 1962. Washington: U. S. Government Printing Office, 1962.

Agricultural Statistics, 1967. Washington: U. S. Government Printing Office, 1967.

Agricutlural Statistics, 1970. Washington: U. S. Government Printing Office, 1970.

Fruit and Vegetable Prices, 1970. Consumer and Marketing Division, Fruit and Vegetable Division, Statistical Bulletin No. 486. Washington: U.S. Department of Agriculture, 1971.

Household Food Consumption Survey, 1965-66. Agricultural Research Service Reports No. 1-5. Washington: U. S. Government Printing Office, 1968.

Household Food Consumption Survey, 1955. Agricultural Research Service Reports No. 1-5. Washington: U. S. Government Printing Office, 1957.

1967 Regional Summary of Fruit Tree Surveys, Selected Appalachian States. Statistical Reporting Service, Crop Reporting Board, U. S. Department of Agriculture. Washington: U. S. Department of Agriculture, 1968.

1968 Regional Summary of Fruit Tree Surveys, Selected Central States.

Statistical Reporting Service, Crop Reporting Board, U. S. Department of Agriculture. Washington: U. S. Department of Agriculture.

- Statistical Abstract of the United States, 1970. Washington: U. S. Government Printing Office, 1970. 
Zuroske, C. H. Apple Production Costs and Returns. Washington Agricultural Experiment Station Bulletin 696. Washington State University, 1968.

\section{LETTERS}

Barnard, H. D., Diamond Fruit Growers, Inc., Hood River, Oregon, personal letter, September 16, 1971

Copple, Harold, Nuchief Sales, Inc., Wenatchee, Washington, personal letter, September 20, 1971.

Gephard, Bill, United Apple Sales, Inc., Milton, New York, personal letter, September 29, 1971.

Lenk Produce, Inc., Holland, Michigan, personal letter.

Miller, Jim, Jim Miller Company, Los Angeles, California, personal letter, September 23, 1971.

Orvold, Leonard, Agricultural Statistician in Charge, Statistical Reporting Service, Portland, Oregon, personal letter, December 14, 1971.

Shawyer, Jan M., Blue Goose Growers, Inc., Hagerstown, Maryland, personal letter.

Wilcox, Emery, Agricultural Statistician in Charge, Statistical Reporting Service, Seattle, Washington, personal letter, December 13, 1971. 
APPENDIX TABLE A

DATA USED TO ADJUST FOR REGIONAL DIFFERENCES IN CONSUMPTION

\begin{tabular}{|c|c|c|c|c|}
\hline $\begin{array}{l}\text { Region } \\
\text { (1) }\end{array}$ & $\begin{array}{l}\text { Weekly Household Fresh } \\
\text { Apple Consumption }{ }^{\mathrm{a}} \\
\text { (2) }\end{array}$ & $\begin{array}{c}\text { Average House- } \\
\text { hold }^{\text {b }} \text { Size } \\
\text { (3) }\end{array}$ & $\begin{array}{l}\text { Annual Per Capita Fresh } \\
\text { Apple Consumption }{ }^{c} \\
\text { (4) }\end{array}$ & $\begin{array}{l}\text { Per Cent of Overall } \\
\text { U.S. Consumption }{ }^{d} \\
\text { (5) }\end{array}$ \\
\hline $\begin{array}{l}1955 \\
\text { Northeast } \\
\text { North Central } \\
\text { West } \\
\text { South } \\
\text { U. S. }\end{array}$ & $\begin{array}{c}\text { Pounds } \\
1.31 \\
1.39 \\
1.31 \\
1.20 \\
1.30\end{array}$ & $\begin{array}{c}\text { Persons } \\
3.20 \\
3.31 \\
3.15 \\
3.52 \\
3.33\end{array}$ & $\begin{array}{c}\text { Pounds } \\
21.29 \\
21.83 \\
21.62 \\
17.72 \\
20.30\end{array}$ & $\begin{array}{c}\text { Per Cent } \\
103 \\
112 \\
109 \\
84\end{array}$ \\
\hline \multicolumn{5}{|l|}{$1965-66$} \\
\hline $\begin{array}{l}\text { Northeast } \\
\text { North Central } \\
\text { West } \\
\text { South } \\
\text { U. S. }\end{array}$ & $\begin{array}{l}1.42 \\
1.59 \\
1.43 \\
1.15 \\
1.38\end{array}$ & $\begin{array}{l}3.28 \\
3.38 \\
3.13 \\
3.28 \\
3.29\end{array}$ & $\begin{array}{l}22.50 \\
24.46 \\
23.75 \\
18.23 \\
21.81\end{array}$ & $\begin{array}{r}105 \\
108 \\
106 \\
87\end{array}$ \\
\hline
\end{tabular}

${ }^{a}$ U. S. Department of Agriculture, Agricultural Research Service, Household Food Consumption Survey, 1955. Report No. 1, p. 124; Report No. 2, p. 123; Reports No. 3 and 4, p. 124; Report No. 5, p. 122; 1965-66. Reports No. 1-5, p. 39 (U.S. Government Printing Office, 1957, 1968).

b/bid., 1955. Report No. 1, p. 17; Report No. 2, p. 16; Report No. 3, p. 17; Report No. 4, p. 17; Report No. 5, p. 15; 1965-66. Reports No. 1-5, p. 1.

${ }^{\mathrm{c}}$ Calculated by dividing data in column (2) by data in column (3) and multiplying by 52 .

${ }^{d}$ Calculated by dividing regional annual per capita consumption by overall United States consumption. 
APPENDIX TABLE B

DATA USED TO ESTIMATE REGIONAL CONSUMPTION AND ESTIMATE OF

REGIONAL CONSUMPTION

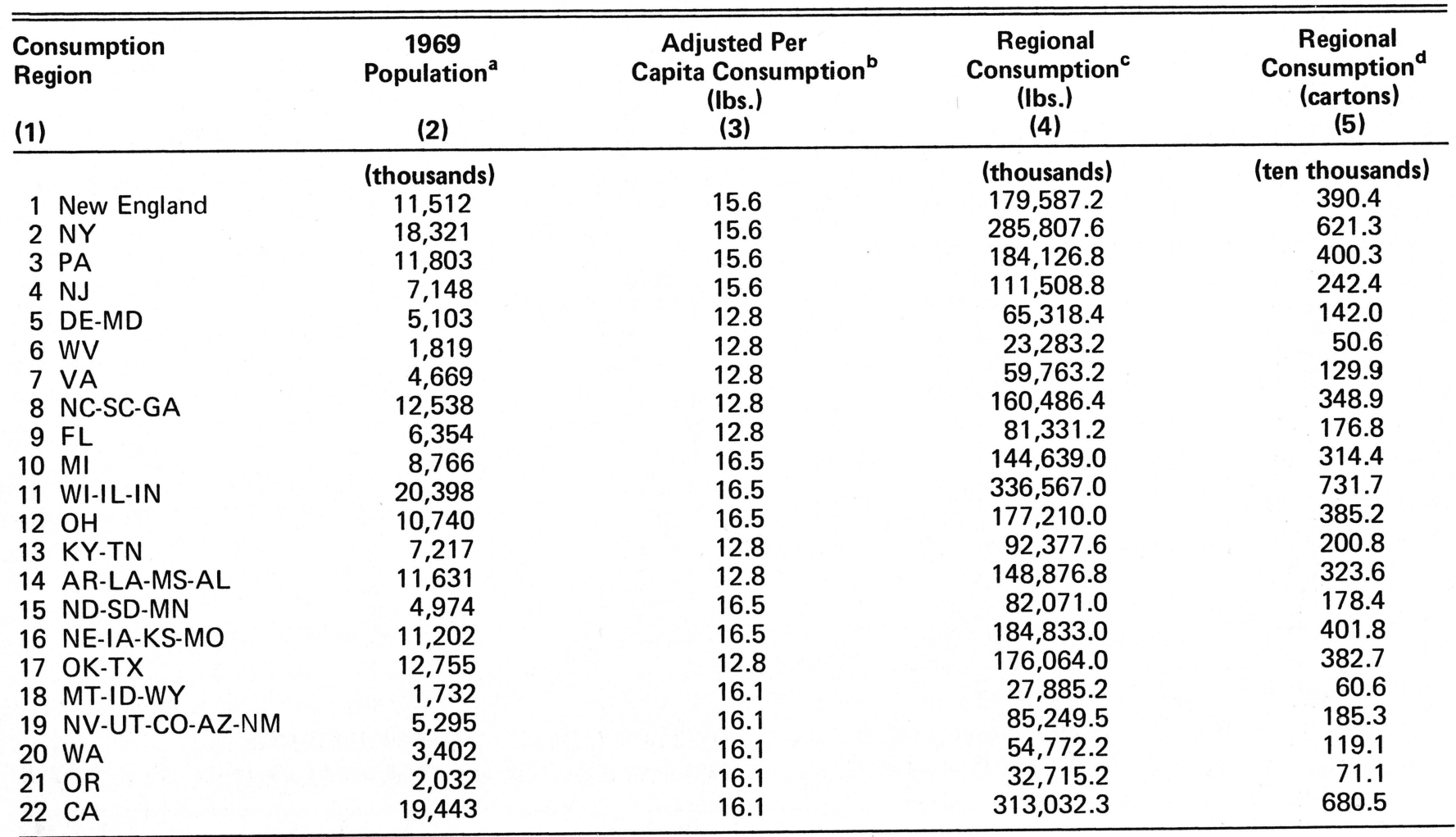

${ }^{\mathrm{a}}$ Taken from Table 1.

${ }^{b}$ Computed by multiplying the mean relative per capita consumption from the 1955 and $1965-66$ ARS household consumption surveys for each ARS region by the 1969 ERS per capita consumption estimate.

${ }^{C}$ Computed by multiplying data in column (2) by data in column (3). 
APPENDIX TABLE C

ACTUAL AND ESTIMATED TRANSPORTATION CHARGES FOR THE BASIC MODEL BETWEEN SELECTED PRODUCTION AND SELECTED CONSUMPTION REGIONS

\begin{tabular}{|c|c|c|c|c|c|c|c|c|}
\hline \multirow[b]{3}{*}{$\begin{array}{l}\text { Production } \\
\text { Region }\end{array}$} & \multicolumn{8}{|c|}{ Consumption Region } \\
\hline & \multicolumn{4}{|c|}{ NEW ENGLAND } & \multicolumn{4}{|c|}{ NY } \\
\hline & $\begin{array}{l}\text { Distance }^{\mathbf{a}, \mathbf{b}} \\
\text { (Miles) }^{\text {Miles }}\end{array}$ & $\begin{array}{l}\text { Direction } \\
\text { of } \\
\text { Shipment }\end{array}$ & $\begin{array}{c}\text { Prediction } \\
\text { Equation } \\
\text { Used }^{c}\end{array}$ & $\begin{array}{l}\text { Cost } \\
\text { Per } \\
\text { Carton }\end{array}$ & $\begin{array}{c}\text { Distance }^{\mathrm{a}, \mathrm{b}} \\
\text { (Miles) }^{-}\end{array}$ & $\begin{array}{c}\text { Direction } \\
\text { of } \\
\text { Shipment }\end{array}$ & $\begin{array}{l}\text { Prediction } \\
\text { Equation } \\
\text { Used }^{c}\end{array}$ & $\begin{array}{l}\text { Cost } \\
\text { Per } \\
\text { Carton }\end{array}$ \\
\hline New England & 39 & $E$ & 3 & $\$ 0.17$ & 175 & $\mathrm{~s}$ & 2 & $\$ 0.32$ \\
\hline New York & - & $E$ & - & $0.30^{d}$ & - & $S$ & - & $0.25^{d}$ \\
\hline Pennsylvania & 447 & E & 3 & 0.53 & 251 & $E$ & 3 & 0.36 \\
\hline West Virginia & 486 & $E$ & 3 & 0.56 & - & $\mathrm{E}$ & - & $0.35^{e}$ \\
\hline Virginia & 1,577 & $\mathrm{~N}$ & 1 & 1.28 & 464 & $\mathrm{~N}$ & 1 & 0.59 \\
\hline Michigan & 924 & $E$ & 8 & 0.65 & - & $E$ & - & $0.60^{f}$ \\
\hline Washington & 2,912 & $E$ & 6 & 1.51 & - & E & - & $1.65^{\mathrm{g}}$ \\
\hline Oregon & 2,992 & $E$ & 6 & 1.55 & - & $\mathrm{E}$ & - & $1.65^{\mathrm{h}}$ \\
\hline California & 3,235 & $E$ & 6 & 1.66 & 2,995 & $E$ & 6 & 1.55 \\
\hline
\end{tabular}


APPENDIX TABLE C (Continued)

\begin{tabular}{|c|c|c|c|c|c|c|c|c|}
\hline \multirow[b]{3}{*}{$\begin{array}{l}\text { Production } \\
\text { Region }\end{array}$} & \multicolumn{8}{|c|}{ Consumption Region } \\
\hline & \multicolumn{4}{|c|}{ PA } & \multicolumn{4}{|c|}{ NJ } \\
\hline & $\begin{array}{c}\text { Distance }^{a, b} \\
\text { (Miles) }\end{array}$ & $\begin{array}{c}\text { Direction } \\
\text { of } \\
\text { Shipment }\end{array}$ & $\begin{array}{c}\text { Prediction } \\
\text { Equation } \\
\text { Used }^{c}\end{array}$ & $\begin{array}{l}\text { Cost } \\
\text { Per } \\
\text { Carton }\end{array}$ & $\begin{array}{l}\text { Distance }^{a, b} \\
\quad \text { (Miles) }\end{array}$ & $\begin{array}{c}\text { Direction } \\
\text { of } \\
\text { Shipment }\end{array}$ & $\begin{array}{c}\text { Prediction } \\
\text { Equation } \\
\text { Used }^{c}\end{array}$ & $\begin{array}{l}\text { Cost } \\
\text { Per } \\
\text { Carton }\end{array}$ \\
\hline New England & 265 & $\mathrm{~s}$ & 2 & $\$ 0.36$ & 185 & $\mathrm{~S}$ & 2 & $\$ 0.33$ \\
\hline New York & - & $\mathrm{S}$ & - & $0.30^{d}$ & 126 & S & 2 & 0.31 \\
\hline Pennsylvania & 189 & $E$ & 3 & 0.30 & 229 & $E$ & 3 & 0.34 \\
\hline West Virginia & - & $E$ & - & $0.30^{\mathrm{e}}$ & - & $\mathrm{E}$ & - & $0.35^{\mathrm{e}}$ \\
\hline Virginia & 442 & $\mathrm{~N}$ & 1 & 0.58 & 362 & $\mathrm{~N}$ & 1 & 0.53 \\
\hline Michigan & - & $E$ & - & $0.55^{f}$ & - & $E$ & - & $0.60^{f}$ \\
\hline Washington & - & $E$ & - & $1.65^{g}$ & 2,741 & $\mathrm{E}$ & 6 & $1.65^{\mathrm{j}}$ \\
\hline Oregon & - & $\mathrm{E}$ & - & $1.65^{\mathrm{h}}$ & 2,821 & $E$ & 6 & $1.65^{\mathrm{j}}$ \\
\hline California & 2,911 & $E$ & 6 & 1.51 & 2,973 & $E$ & 6 & 1.54 \\
\hline
\end{tabular}


APPENDIX TABLE C (Continued)

\begin{tabular}{|c|c|c|c|c|c|c|c|c|}
\hline \multirow[b]{3}{*}{$\begin{array}{l}\text { Production } \\
\text { Region }\end{array}$} & \multicolumn{8}{|c|}{ Consumption Region } \\
\hline & \multicolumn{4}{|c|}{ DE-MD } & \multicolumn{4}{|c|}{ WV } \\
\hline & $\begin{array}{l}\text { Distance } \text {, }^{\mathbf{b} b} \\
\text { (Miles) }\end{array}$ & $\begin{array}{c}\text { Direction } \\
\text { of } \\
\text { Shipment }\end{array}$ & $\begin{array}{c}\text { Prediction } \\
\text { Equation } \\
\text { Used }^{c}\end{array}$ & $\begin{array}{l}\text { Cost } \\
\text { Per } \\
\text { Carton }\end{array}$ & $\begin{array}{l}\text { Distance }^{\mathbf{a}, \mathrm{b}} \\
\text { (Miles) }^{-}\end{array}$ & $\begin{array}{c}\text { Direction } \\
\text { of } \\
\text { Shipment }\end{array}$ & $\begin{array}{l}\text { Prediction } \\
\text { Equation } \\
\text { Used }\end{array}$ & $\begin{array}{l}\text { Cost } \\
\text { Per } \\
\text { Carton }\end{array}$ \\
\hline New England & 361 & $S$ & 2 & $\$ 0.39$ & 719 & W & 4 & $\$ 0.60$ \\
\hline New York & - & $\mathrm{S}$ & - & $0.35^{d}$ & 622 & $\mathrm{~s}$ & 2 & 0.48 \\
\hline Pennsylvania & 161 & $\mathrm{~S}$ & 2 & 0.32 & 348 & $S$ & 2 & 0.39 \\
\hline West Virginia & - & $E$ & - & $0.18^{e}$ & 285 & w & 4 & 0.45 \\
\hline Virginia & 266 & $E$ & 3 & 0.37 & 163 & W & 4 & 0.41 \\
\hline Michigan & - & $E$ & - & $0.50^{f}$ & - & $S$ & - & $0.50^{f}$ \\
\hline Washington & - & $E$ & - & $1.65^{g}$ & - & $E$ & - & $1.40^{9}$ \\
\hline Oregon & - & $E$ & - & $1.65^{\mathrm{h}}$ & - & E & - & $1.40^{\mathrm{h}}$ \\
\hline California & 2,840 & $E$ & 6 & 1.28 & 2,636 & $E$ & 6 & 1.39 \\
\hline
\end{tabular}


APPENDIX TABLE C (Continued)

\begin{tabular}{|c|c|c|c|c|c|c|c|c|}
\hline \multirow[b]{3}{*}{$\begin{array}{l}\text { Production } \\
\text { Region }\end{array}$} & \multicolumn{8}{|c|}{ Consumption Region } \\
\hline & \multicolumn{4}{|c|}{ VA } & \multicolumn{4}{|c|}{ NC-SC-GA } \\
\hline & $\begin{array}{l}\text { Distance } \text { e }^{a, b} \\
\text { (Miles) }\end{array}$ & $\begin{array}{l}\text { Direction } \\
\text { of } \\
\text { Shipment }\end{array}$ & $\begin{array}{c}\text { Prediction } \\
\text { Equation } \\
\text { Used }^{c}\end{array}$ & $\begin{array}{l}\text { Cost } \\
\text { Per } \\
\text { Carton }\end{array}$ & $\begin{array}{l}\text { Distance }^{a, b} \\
\text { (Miles) }\end{array}$ & $\begin{array}{c}\text { Direction } \\
\text { of } \\
\text { Shipment }\end{array}$ & $\begin{array}{c}\text { Prediction } \\
\text { Equation } \\
\text { Used }^{c}\end{array}$ & $\begin{array}{l}\text { Cost } \\
\text { Per } \\
\text { Carton }\end{array}$ \\
\hline New England & 508 & S & 2 & $\$ 0.44$ & 867 & $\mathrm{~S}$ & 2 & $\$ 0.57$ \\
\hline New York & 442 & $\mathrm{~S}$ & 2 & 0.42 & 801 & $\mathrm{~s}$ & 2 & 0.55 \\
\hline Pennsylvania & 282 & $\mathrm{~s}$ & 2 & 0.36 & 598 & $\mathrm{~s}$ & 2 & 0.48 \\
\hline West Virginia & 211 & $\mathrm{~s}$ & 2 & 0.34 & - & $\mathrm{s}$ & - & $0.45^{\mathrm{e}}$ \\
\hline Virginia & 183 & $E$ & 3 & 0.30 & 275 & $\mathrm{~S}$ & 2 & 0.36 \\
\hline Michigan & - & $E$ & - & $0.55^{f}$ & - & $\mathrm{s}$ & - & $0.50^{f}$ \\
\hline Washington & - & $E$ & - & $1.55^{g}$ & - & $E$ & - & $1.40^{9}$ \\
\hline Oregon & - & $\mathrm{E}$ & - & $1.55^{\mathrm{h}}$ & - & $E$ & - & $1.40^{\mathrm{h}}$ \\
\hline California & 2,835 & $\bar{E}$ & 6 & 1.48 & 2,681 & $\mathrm{E}$ & 6 & 1.41 \\
\hline
\end{tabular}




\section{APPENDIX TABLE C (Continued)}

\begin{tabular}{|c|c|c|c|c|c|c|c|c|}
\hline \multirow[b]{3}{*}{$\begin{array}{l}\text { Production } \\
\text { Region }\end{array}$} & \multicolumn{8}{|c|}{ Consumption Region } \\
\hline & \multicolumn{4}{|c|}{$\mathbf{F L}$} & \multicolumn{4}{|c|}{ MI } \\
\hline & $\begin{array}{c}\text { Distance }^{a, b} \\
\text { (Miles) }\end{array}$ & $\begin{array}{c}\text { Direction } \\
\text { of } \\
\text { Shipment }\end{array}$ & $\begin{array}{c}\text { Prediction } \\
\text { Equation } \\
\text { Used }^{c}\end{array}$ & $\begin{array}{l}\text { Cost } \\
\text { Per } \\
\text { Carton }\end{array}$ & $\begin{array}{l}\text { Distance }^{a, b} \\
\quad \text { (Miles) }\end{array}$ & $\begin{array}{c}\text { Direction } \\
\text { of } \\
\text { Shipment }\end{array}$ & $\begin{array}{c}\text { Prediction } \\
\text { Equation } \\
\text { Used }^{c}\end{array}$ & $\begin{array}{l}\text { Cost } \\
\text { Per } \\
\text { Carton }\end{array}$ \\
\hline New England & 1,216 & $\mathrm{~S}$ & 2 & $\$ 0.70$ & 756 & W & 4 & $\$ 0.61$ \\
\hline New York & 1,150 & $S$ & 2 & 0.53 & 679 & w & 4 & 0.58 \\
\hline Pennsylvania & 944 & $S$ & 2 & 0.60 & 393 & W & 4 & 0.49 \\
\hline West Virginia & 873 & $S$ & 2 & 0.58 & - & w & - & $0.55^{\mathrm{e}}$ \\
\hline Virginia & 621 & $S$ & 2 & 0.48 & 542 & $\mathrm{~N}$ & 1 & 0.64 \\
\hline Michigan & 1,019 & $\mathrm{~S}$ & 7 & 0.55 & 172 & $E$ & 8 & 0.37 \\
\hline Washington & - & $E$ & - & $1.35^{\mathrm{g}}$ & - & $E$ & - & $1.30^{\mathrm{g}}$ \\
\hline Oregon & - & $E$ & - & $1.35^{h}$ & - & $\mathrm{E}$ & - & $1.30^{\mathrm{h}}$ \\
\hline California & 2,545 & $\mathrm{E}$ & 6 & 1.35 & 2,475 & $\mathrm{E}$ & 6 & 1.32 \\
\hline
\end{tabular}


APPENDIX TABLE C (Continued)

\begin{tabular}{|c|c|c|c|c|c|c|c|c|}
\hline \multirow[b]{3}{*}{$\begin{array}{l}\text { Production } \\
\text { Region }\end{array}$} & \multicolumn{8}{|c|}{ Consumption Region } \\
\hline & \multicolumn{4}{|c|}{ WI-IL-IN } & \multicolumn{4}{|c|}{$\mathrm{OH}$} \\
\hline & $\begin{array}{c}\text { Distance }^{\mathrm{a}, \mathrm{b}} \\
\text { (Miles) }\end{array}$ & $\begin{array}{l}\text { Direction } \\
\text { of } \\
\text { Shipment }\end{array}$ & $\begin{array}{c}\text { Prediction } \\
\text { Equation } \\
\text { Used }^{c}\end{array}$ & $\begin{array}{l}\text { Cost } \\
\text { Per } \\
\text { Carton }\end{array}$ & $\begin{array}{l}\text { Distance }^{a, b} \\
\text { (Miles) }\end{array}$ & $\begin{array}{c}\text { Direction } \\
\text { of } \\
\text { Shipment }\end{array}$ & $\begin{array}{c}\text { Prediction } \\
\text { Equation } \\
\text { Used }^{c}\end{array}$ & $\begin{array}{l}\text { Cost } \\
\text { Per } \\
\text { Carton }\end{array}$ \\
\hline New England & 923 & W & 4 & $\$ 0.66$ & 709 & w & 4 & $\$ 0.59$ \\
\hline New York & - & W & - & $0.50^{\mathrm{d}}$ & 612 & W & 4 & 0.56 \\
\hline Pennsylvania & 560 & W & 4 & 0.54 & 322 & W & 4 & 0.46 \\
\hline West Virginia & - & w & - & $0.55^{\mathrm{e}}$ & - & W & - & $0.45^{e}$ \\
\hline Virginia & 644 & W & 4 & 0.57 & 352 & W & 4 & 0.47 \\
\hline Michigan & - & $\mathrm{S}$ & - & $0.25^{f}$ & - & $\mathrm{E}$ & - & $0.40^{f}$ \\
\hline Washington & - & $E$ & - & $1.10^{g}$ & - & $\bar{E}$ & - & $1.25^{9}$ \\
\hline Oregon & - & $E$ & - & $1.10^{\mathrm{h}}$ & - & $E$ & - & $1.25^{\mathrm{h}}$ \\
\hline California & 2,215 & $E$ & 6 & 1.21 & 2,513 & $E$ & 6 & 1.34 \\
\hline
\end{tabular}


APPENDIX TABLE C (Continued)

\begin{tabular}{|c|c|c|c|c|c|c|c|c|}
\hline \multirow[b]{3}{*}{$\begin{array}{l}\text { Production } \\
\text { Region }\end{array}$} & \multicolumn{8}{|c|}{ Consumption Region } \\
\hline & \multicolumn{4}{|c|}{ KY-TN } & \multicolumn{4}{|c|}{ AR-LA-MS-AL } \\
\hline & $\begin{array}{l}\text { Distance }^{a, b} \\
\text { (Miles) }^{\text {(M) }}\end{array}$ & $\begin{array}{c}\text { Direction } \\
\text { of } \\
\text { Shipment }\end{array}$ & $\begin{array}{c}\text { Prediction } \\
\text { Equation } \\
\text { Used }^{c}\end{array}$ & $\begin{array}{l}\text { Cost } \\
\text { Per } \\
\text { Carton }\end{array}$ & $\begin{array}{l}\text { Distance }^{a, b} \\
\text { (Miles) }\end{array}$ & $\begin{array}{c}\text { Direction } \\
\text { of } \\
\text { Shipment }\end{array}$ & $\begin{array}{c}\text { Prediction } \\
\text { Equation }^{\text {Used }} \\
\text { U }^{\mathbf{c}}\end{array}$ & $\begin{array}{l}\text { Cost } \\
\text { Per } \\
\text { Carton }\end{array}$ \\
\hline New England & 1,056 & W & 4 & $\$ 0.71$ & 1,380 & w & 4 & $\$ 0.81$ \\
\hline New York & 965 & W & 4 & 0.68 & 1,289 & $\mathrm{~S}$ & 2 & 0.72 \\
\hline Pennsylvania & 696 & W & 4 & 0.59 & 1,068 & $\mathrm{~S}$ & 2 & 0.65 \\
\hline West Virginia & 612 & W & 4 & 0.56 & 936 & $S$ & 2 & 0.60 \\
\hline Virginia & 435 & W & 4 & 0.50 & 759 & w & 4 & 0.61 \\
\hline Michigan & - & $\mathrm{s}$ & - & $0.45^{f}$ & - & $\mathrm{s}$ & - & $0.55^{f}$ \\
\hline Washington & - & $E$ & - & $1.25^{\mathrm{g}}$ & - & $\mathrm{E}$ & - & $1.15^{\mathrm{g}}$ \\
\hline Oregon & - & $\mathrm{E}$ & - & $1.25^{\mathrm{h}}$ & - & $\mathrm{E}$ & - & $1.15^{\mathrm{h}}$ \\
\hline California & 2,303 & $E$ & 6 & 1.24 & 2,119 & $E$ & 6 & 1.16 \\
\hline
\end{tabular}


APPENDIX TABLE C (Continued)

\begin{tabular}{|c|c|c|c|c|c|c|c|c|}
\hline \multirow[b]{3}{*}{$\begin{array}{l}\text { Production } \\
\text { Region }\end{array}$} & \multicolumn{8}{|c|}{ Consumption Region } \\
\hline & \multicolumn{4}{|c|}{ ND-SD-MN } & \multicolumn{4}{|c|}{ NE-IA-KS-MO } \\
\hline & $\begin{array}{l}\text { Distance }^{\mathbf{a}, \mathbf{b}} \\
\text { (Miles) }\end{array}$ & $\begin{array}{c}\text { Direction } \\
\text { of } \\
\text { Shipment }\end{array}$ & $\begin{array}{l}\text { Prediction } \\
\text { Equation } \\
\text { Used }^{c}\end{array}$ & $\begin{array}{l}\text { Cost } \\
\text { Per } \\
\text { Carton }\end{array}$ & $\begin{array}{l}\text { Distance }^{a, b} \\
\quad \text { (Miles) }\end{array}$ & $\begin{array}{c}\text { Direction } \\
\text { of } \\
\text { Shipment }\end{array}$ & $\begin{array}{c}\text { Prediction } \\
\text { Equation } \\
\text { Used }^{c}\end{array}$ & $\begin{array}{l}\text { Cost } \\
\text { Per } \\
\text { Carton }\end{array}$ \\
\hline New England & 1,325 & w & 4 & $\$ 0.80$ & 1,362 & W & 4 & $\$ 0.81$ \\
\hline New York & 1,248 & w & 4 & 0.77 & 1,265 & w & 4 & 0.78 \\
\hline Pennsylvania & 962 & w & 4 & 0.68 & 975 & w & 4 & 0.68 \\
\hline West Virginia & - & W & - & $0.70^{\mathrm{e}}$ & - & W & - & $0.80^{\mathrm{e}}$ \\
\hline Virginia & 1,046 & w & 4 & 0.70 & 955 & W & 4 & 0.67 \\
\hline Michigan & - & W & - & $0.40^{f}$ & 628 & w & 9 & 0.48 \\
\hline Washington & - & $\mathrm{E}$ & - & $0.88^{\mathrm{g}}$ & - & $\mathrm{E}$ & - & $0.95^{9}$ \\
\hline Oregon & - & $E$ & - & $0.88^{h}$ & - & $\mathrm{E}$ & - & $0.95^{h}$ \\
\hline California & 2,016 & $\mathrm{E}$ & 6 & 1.12 & 1,795 & $E$ & 6 & 1.02 \\
\hline
\end{tabular}


APPENDIX TABLE C (Continued)

\begin{tabular}{|c|c|c|c|c|c|c|c|c|}
\hline \multirow[b]{3}{*}{$\begin{array}{l}\text { Production } \\
\text { Region }\end{array}$} & \multicolumn{8}{|c|}{ Consumption Region } \\
\hline & \multicolumn{4}{|c|}{ OK-TX } & \multicolumn{4}{|c|}{ MT-ID-WY } \\
\hline & $\begin{array}{l}\text { Distance }^{\mathrm{a}, \mathrm{b}} \\
\text { (Miles) }\end{array}$ & $\begin{array}{c}\text { Direction } \\
\text { of } \\
\text { Shipment }\end{array}$ & $\begin{array}{l}\text { Prediction } \\
\text { Equation } \\
\text { Used }^{\mathbf{c}}\end{array}$ & $\begin{array}{l}\text { Cost } \\
\text { Per } \\
\text { Carton }\end{array}$ & $\begin{array}{l}\text { Distance }{ }^{\mathbf{a}, \mathbf{b}} \\
\text { (Miles) }\end{array}$ & $\begin{array}{c}\begin{array}{c}\text { Direction } \\
\text { of }\end{array} \\
\text { Shipment }\end{array}$ & $\begin{array}{c}\text { Prediction } \\
\text { Equation } \\
\text { Used }^{c}\end{array}$ & $\begin{array}{l}\text { Cost } \\
\text { Per } \\
\text { Carton }\end{array}$ \\
\hline New England & 1,729 & $S$ & 2 & $\$ 0.88$ & 2,373 & W & 4 & $\$ 1.14$ \\
\hline New York & 1,638 & W & 4 & 0.90 & 2,296 & W & 4 & 1.12 \\
\hline Pennsylvania & 1,355 & W & 4 & 0.81 & 2,010 & w & 4 & 1.02 \\
\hline West Virginia & 1,285 & W & 4 & 0.78 & 2,017 & w & 4 & 1.02 \\
\hline Virginia & 1,108 & w & 4 & 0.72 & 2,094 & w & 4 & 1.05 \\
\hline Michigan & - & $\mathrm{s}$ & - & $0.60^{f}$ & 1,594 & w & 9 & 0.79 \\
\hline Washington & - & $E$ & - & $1.10^{\mathrm{g}}$ & - & $\mathrm{E}$ & - & $0.50^{g}$ \\
\hline Oregon & - & $E$ & - & $1.10^{\mathrm{h}}$ & - & $\mathrm{E}$ & - & $0.50^{\mathrm{h}}$ \\
\hline California & 1,714 & $E$ & 6 & 0.99 & 1,080 & $E$ & 6 & 0.71 \\
\hline
\end{tabular}


APPENDIX TABLE C (Continued)

\begin{tabular}{|c|c|c|c|c|c|c|c|c|}
\hline \multirow[b]{3}{*}{$\begin{array}{l}\text { Production } \\
\text { Region }\end{array}$} & \multicolumn{8}{|c|}{ Consumption Region } \\
\hline & \multicolumn{4}{|c|}{ NV-UT-CO-AZ-NM } & \multicolumn{4}{|c|}{ WA } \\
\hline & $\begin{array}{l}\text { Distance }^{\mathrm{a}, \mathrm{b}} \\
\text { (Miles) }\end{array}$ & $\begin{array}{c}\text { Direction } \\
\text { of } \\
\text { Shipment }\end{array}$ & $\begin{array}{l}\text { Prediction } \\
\text { Equation } \\
\text { Used }\end{array}$ & $\begin{array}{l}\text { Cost } \\
\text { Per } \\
\text { Carton }\end{array}$ & $\begin{array}{l}\text { Distance }^{\mathbf{a}, \mathbf{b}} \\
\text { (Miles) }^{-}\end{array}$ & $\begin{array}{l}\text { Direction } \\
\text { of } \\
\text { Shipment }\end{array}$ & $\begin{array}{l}\text { Prediction } \\
\text { Equation } \\
\text { Used }^{\mathrm{c}}\end{array}$ & $\begin{array}{l}\text { Cost } \\
\text { Per } \\
\text { Carton }\end{array}$ \\
\hline New England & 2,578 & W & 4 & $\$ 1.21$ & 2,953 & W & 4 & $\$ 1.33$ \\
\hline New York & 2,481 & w & 4 & 1.18 & 2,876 & W & 4 & 1.31 \\
\hline Pennsylvania & 2,191 & w & 4 & 1.08 & 2,590 & w & 4 & 1.21 \\
\hline West Virginia & 2,161 & w & 4 & 1.07 & 2,597 & w & 4 & 1.22 \\
\hline Virginia & 2,094 & W & 4 & 1.05 & 2,674 & W & 4 & 1.24 \\
\hline Michigan & 1,895 & w & 9 & 0.87 & 2,174 & W & 9 & 0.98 \\
\hline Washington & - & $\mathrm{S}$ & - & $0.75^{\mathrm{g}}$ & 141 & $\mathrm{~N}$ & 5 & 0.22 \\
\hline Oregon & - & $\mathrm{S}$ & - & $0.75^{\mathrm{h}}$ & 224 & $\mathrm{~N}$ & 5 & 0.25 \\
\hline California & 732 & $E$ & 6 & 0.55 & 874 & $\mathrm{~N}$ & 5 & 0.56 \\
\hline
\end{tabular}


APPENDIX TABLE C (Continued)

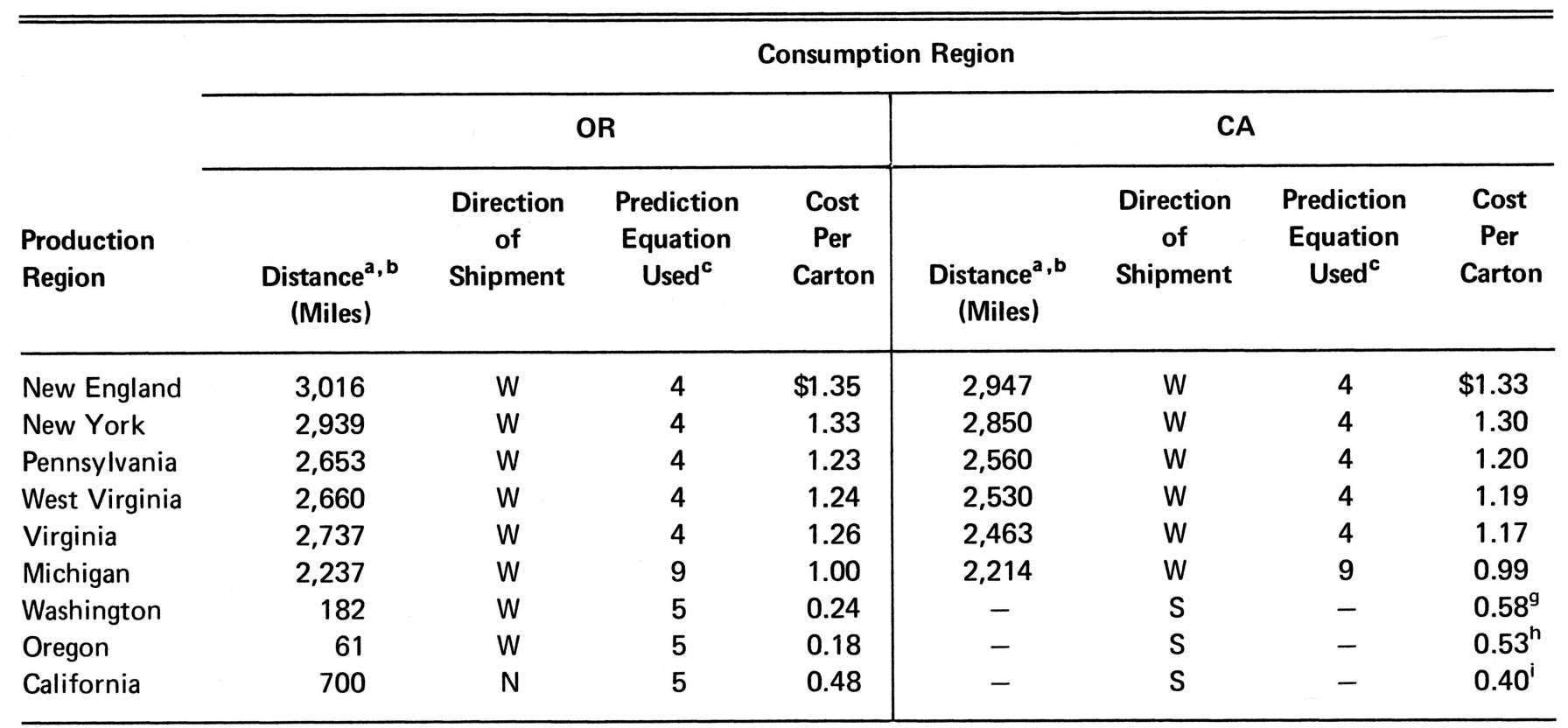




\section{APPENDIX TABLE C (Continued)}

${ }^{\text {a }}$ Mileages and estimates of transportation charges are given only for those cases where the transportation rate was estimated.

${ }^{\mathrm{b}}$ Taken from Household Goods Carriers Bureau, Mileage Guide No. 9 (Washington, 1967).

${ }^{\mathrm{C}}$ Taken from Table 2 .

dLetter from Bill Gephard, United Apple Sales, Inc., Milton, New York, September 29, 1971.

e Letter from Jan M. Shawyer, Blue Goose Growers, Inc., Hagerstown, Maryland.

fLetter from Lenk Produce, Inc., Holland, Michigan.

${ }^{g}$ Letter from Harold Copple, Nuchief Sales, Inc., Wenatchee, Washington, September 20, 1971

hLetter from H. D. Barnard, Diamond Fruit Growers, Inc., Hood River, Oregon, September 16, 1971.

'Letter from Jim Miller, Jim Miller Company, Los Angeles, California, September 23, 1971.

${ }^{\mathrm{j}}$ Changed to $\$ 1.65$ to agree with actual transportation rates from Washington and Oregon to New York, Philadelphia, and Baltimore. 
PRODUCTION COSTS PER ACRE FOR SEVEN MAJOR APPLE-PRODUCING STATES UPDATED TO 1970: MAINE

\begin{tabular}{|c|c|c|c|c|c|}
\hline \multirow[b]{2}{*}{$\begin{array}{l}\text { Cost Item } \\
\text { (1) }\end{array}$} & \multirow[b]{2}{*}{$\begin{array}{c}\text { Description of Cost Item } \\
\text { (2) }\end{array}$} & \multirow{2}{*}{$\begin{array}{l}1956 \\
\text { Unadjusted } \\
\text { Cost }^{\mathrm{a}} \\
\text { (3) }\end{array}$} & \multicolumn{2}{|c|}{$\begin{array}{l}\text { U.S. Indexes } \\
(1910-14=100)\end{array}$} & \multirow{2}{*}{$\begin{array}{l}1970 \\
\text { Adjustec } \\
\text { Cost }^{c} \\
\text { (6) }\end{array}$} \\
\hline & & & $\begin{array}{c}1956 \\
\text { Index } \\
\text { (4) }\end{array}$ & $\begin{array}{r}1970 \\
\text { Index } \\
(5)\end{array}$ & \\
\hline Interest & Interest on investment & $\$ 26.00$ & 151 & 611 & $\$ 105.30$ \\
\hline Depreciation & $\begin{array}{l}\text { General overhead, including } \\
\text { equipment and building } \\
\text { repair, depreciation, } \\
\text { insurance, taxes }\end{array}$ & $29.75^{\mathrm{e}}$ & - & - & $(29.75)^{d}$ \\
\hline $\begin{array}{l}\text { Buildings and } \\
\text { Improvements }\end{array}$ & Same as above & $15.25^{e}$ & 371 & 469 & 19.22 \\
\hline $\begin{array}{l}\text { Machinery and } \\
\text { Equipment }\end{array}$ & Operating Equipment & 19.00 & 326 & 537 & 31.35 \\
\hline Labor & $\begin{array}{l}\text { Growing and harvesting } \\
\text { labor costs }\end{array}$ & 175.00 & 536 & 1,083 & 353.50 \\
\hline Materials & $\begin{array}{l}\text { Spray and dust material, } \\
\text { fertilizer and lime }\end{array}$ & 68.00 & 260 & 292 & 76.16 \\
\hline Other & Other & 7.00 & 250 & 314 & 8.82 \\
\hline TOTAL & & $\$ 340.00$ & & & $\$ 624.10$ \\
\hline
\end{tabular}




\section{APPENDIX TABLE D (Continued): NEW YORK}

\begin{tabular}{|c|c|c|c|c|c|}
\hline \multirow[b]{2}{*}{$\begin{array}{l}\text { Cost Item } \\
\text { (1) }\end{array}$} & \multirow[b]{2}{*}{$\begin{array}{c}\text { Description of Cost Item } \\
\text { (2) }\end{array}$} & \multirow{2}{*}{$\begin{array}{c}1956 \\
\text { Unadjusted } \\
\text { Cost }^{\mathrm{a}} \\
\text { (3) }\end{array}$} & \multicolumn{2}{|c|}{$\begin{array}{c}\text { U.S. Indexes } \\
(1910-14=100)\end{array}$} & \multirow{2}{*}{$\begin{array}{l}1970 \\
\text { Adjusted } \\
\text { Cost }^{c} \\
\text { (6) }\end{array}$} \\
\hline & & & $\begin{array}{c}1956 \\
\text { Index } \\
\text { (4) }\end{array}$ & $\begin{array}{r}1970 \\
\text { Index } \\
(5)\end{array}$ & \\
\hline Interest & Interest & $\$ 8.29$ & 569 & 611 & $\$ 8.87$ \\
\hline Depreciation & & None Listed & - & - & - \\
\hline $\begin{array}{l}\text { Buildings and } \\
\text { Improvements }\end{array}$ & & None Listed & - & - & - \\
\hline $\begin{array}{l}\text { Machinery and } \\
\text { Equipment }\end{array}$ & $\begin{array}{l}\text { Tractor work, other } \\
\text { equipment, auto and truck }\end{array}$ & 93.50 & 509 & 537 & 99.11 \\
\hline Labor & $\begin{array}{l}\text { Growing and harvesting } \\
\text { labor costs }\end{array}$ & 207.49 & 1,010 & 1,083 & 222.01 \\
\hline Materials & $\begin{array}{l}\text { Fertilizer and spreading, } \\
\text { spray and dust materials }\end{array}$ & 83.66 & 286 & 292 & 85.33 \\
\hline Other & Orchard overhead, other & 67.31 & 304 & 314 & 69.33 \\
\hline TOTAL & & $\$ 460.25$ & & & $\$ 484.65$ \\
\hline
\end{tabular}




\section{APPENDIX TABLE D (Continued): MICHIGAN}

\begin{tabular}{|c|c|c|}
\hline $\begin{array}{l}\text { Cost Item } \\
\text { (1) }\end{array}$ & $\begin{array}{c}\text { Description of Cost Item } \\
\text { (2) }\end{array}$ & $\begin{array}{l}1970 \\
\text { Unadjusted } \\
\text { Cost } \\
\text { (3) }\end{array}$ \\
\hline Interest & Interest on orchard and land & $\$ 42.00$ \\
\hline Depreciation & Orchard depreciation & 30.00 \\
\hline $\begin{array}{l}\text { Buildings and } \\
\text { Improvements }\end{array}$ & $\begin{array}{l}\text { Machinery variable costs, } \\
\text { machinery and building fixed }\end{array}$ & \\
\hline $\begin{array}{l}\text { Machinery and } \\
\text { Equipment }\end{array}$ & costs & 149.47 \\
\hline Labor & $\begin{array}{l}\text { Growing and harvesting } \\
\text { labor costs }\end{array}$ & 264.58 \\
\hline Materials & Spray and other materials & 104.40 \\
\hline Other & Taxes, other & 32.71 \\
\hline TOTAL & & $\$ 623.16$ \\
\hline
\end{tabular}


APPENDIX TABLE D (Continued): WASHINGTON

\begin{tabular}{|c|c|c|c|c|c|}
\hline Interest & $\begin{array}{l}\text { Interest on investment: } \\
\text { land and orchard, buildings } \\
\text { and improvements, machinery } \\
\text { and equipment }\end{array}$ & $\$ 171.86$ & 377 & 611 & $\$ 278.41$ \\
\hline Decpreciation & $\begin{array}{l}\text { Depreciation on buildings } \\
\text { and improvements, machinery } \\
\text { and equipment: }\end{array}$ & 79.00 & - & - & $(79.00)^{d}$ \\
\hline $\begin{array}{l}\text { Buildings and } \\
\text { Improvements }\end{array}$ & Repairs and maintenance & 12.70 & 391 & 469 & 15.24 \\
\hline Labor & $\begin{array}{l}\text { Orchard labor costs, } \\
\text { harvesting }\end{array}$ & 229.61 & 728 & 1,083 & 342.12 \\
\hline Materials & $\begin{array}{l}\text { Sprays, fertilizer, cover } \\
\text { crop seed, new trees, misc. materials }\end{array}$ & 86.32 & 270 & 292 & 93.22 \\
\hline Other & $\begin{array}{l}\text { Water charges, taxes, ins., } \\
\text { elec., tel., operators } \\
\text { suprv. and mngt., misc. exp. }\end{array}$ & 125.63 & 276 & 314 & 143.22 \\
\hline тחדヘ & & $\$ 682.61$ & & & $\$ 1,008.23$ \\
\hline
\end{tabular}




\begin{tabular}{|c|c|c|c|c|c|}
\hline \multirow[b]{2}{*}{$\begin{array}{l}\text { Cost Item } \\
\text { (1) }\end{array}$} & \multirow[b]{2}{*}{$\begin{array}{l}\text { Description of Cost Item } \\
\text { (2) }\end{array}$} & \multirow{2}{*}{$\begin{array}{l}\text { 1947-56 Ave. } \\
\text { Unadjusted } \\
\text { Cost }^{\mathrm{k}} \\
\text { (3) }\end{array}$} & \multicolumn{2}{|c|}{$\begin{array}{r}\text { U.S. Indexes } \\
(1910-14=100)\end{array}$} & \multirow{2}{*}{$\begin{array}{l}1970 \\
\text { Adjusted } \\
\text { Cost }^{\mathrm{c}} \\
\text { (6) }\end{array}$} \\
\hline & & & $\begin{array}{r}1950 \\
\text { Index } \\
\text { (4) }\end{array}$ & $\begin{array}{c}1970 \\
\text { Index } \\
(5)\end{array}$ & \\
\hline Interest & Interest on bldgs. mach., orchard & $\$ 47.82$ & 89 & 611 & $\$ 328.04$ \\
\hline Depreciation & Depreciation on bldgs., mach. & 30.92 & - & - & $(30.92)^{d}$ \\
\hline $\begin{array}{l}\text { Buildings and } \\
\text { Improvements }\end{array}$ & Building repair & 4.52 & 312 & 469 & 6.78 \\
\hline $\begin{array}{l}\text { Machinery and } \\
\text { Equipment }\end{array}$ & Machinery repair, machine hire & 16.79 & 277 & 537 & 32.57 \\
\hline Labor & Picking and harvesting labor & 261.09 & 425 & 1,083 & 665.78 \\
\hline Materials & $\begin{array}{l}\text { Fertilizers, irrigation } \\
\text { water, sprays, misc. supplies }\end{array}$ & 75.33 & 247 & 292 & 88.89 \\
\hline Other & $\begin{array}{l}\text { Gas, oil, elec., water, wood } \\
\text { fuel, office; liability, } \\
\text { fire, motor ins.; property } \\
\text { taxes, cash to operate }\end{array}$ & 56.81 & 246 & 314 & 72.72 \\
\hline TOTAL & & $\$ 493.28$ & & & $\$ 1,225.70$ \\
\hline
\end{tabular}




\begin{tabular}{|c|c|c|c|c|c|}
\hline $\begin{array}{l}\text { Cost Item } \\
\text { (1) }\end{array}$ & $\begin{array}{l}\text { Description of Cost Item } \\
\text { (2) }\end{array}$ & $\begin{array}{c}1967 \\
\text { Unadjusted } \\
\text { Cost' } \\
\text { (3) }\end{array}$ & $\begin{array}{r}\text { U.S } \\
(1910 \\
1967 \\
\text { Index } \\
\text { (4) }\end{array}$ & $\begin{array}{c}\text { lexes } \\
=100) \\
1970 \\
\text { Index } \\
(5)\end{array}$ & $\begin{array}{c}1970 \\
\text { Adjusted } \\
\text { Cost }^{c} \\
\text { (6) }\end{array}$ \\
\hline Interest & $\begin{array}{l}\text { Interest and depreciation on investment } \\
\text { for trees, bldgs., equip. and housing, irrig. } \\
\text { system, tractors, fork lift, truck and } \\
\text { pickup, sprayer, props, ladders and } \\
\text { pick bags, tillage and other equip., land } \\
\text { at } \$ 1,500\end{array}$ & $\$ 174.30$ & 471 & 611 & $\$ 226.59$ \\
\hline Depreciation & Same as above & 134.70 & - & - & $(134.70)^{d}$ \\
\hline $\begin{array}{l}\text { Buildings and } \\
\text { Improvements }\end{array}$ & $\begin{array}{l}\text { Repairs, except tractors, } \\
\text { truck and sprayer }\end{array}$ & 6.00 & 407 & 469 & 6.90 \\
\hline $\begin{array}{l}\text { Machinery and } \\
\text { Equipment }\end{array}$ & $\begin{array}{l}\text { Truck, tractor-crawler and } \\
\text { wheel tractor }\end{array}$ & 53.56 & 462 & 537 & 62.13 \\
\hline Labor & Preharvest and harvesting costs & 540.52 & 848 & 1,083 & 691.86 \\
\hline Materials & Fertilizer, spray, misc. material, bin rental & 148.00 & 274 & 292 & 156.88 \\
\hline Other & $\begin{array}{l}\text { Water: pumping power, county taxes, office } \\
\text { car, int. on operating capital, etc. }\end{array}$ & 101.55 & 287 & 314 & 110.69 \\
\hline TOTAL & & $\$ 1,158.63$ & & & $\$ 1,389.75$ \\
\hline
\end{tabular}


APPENDIX TABLE D (Continued): PENNSYLVANIA

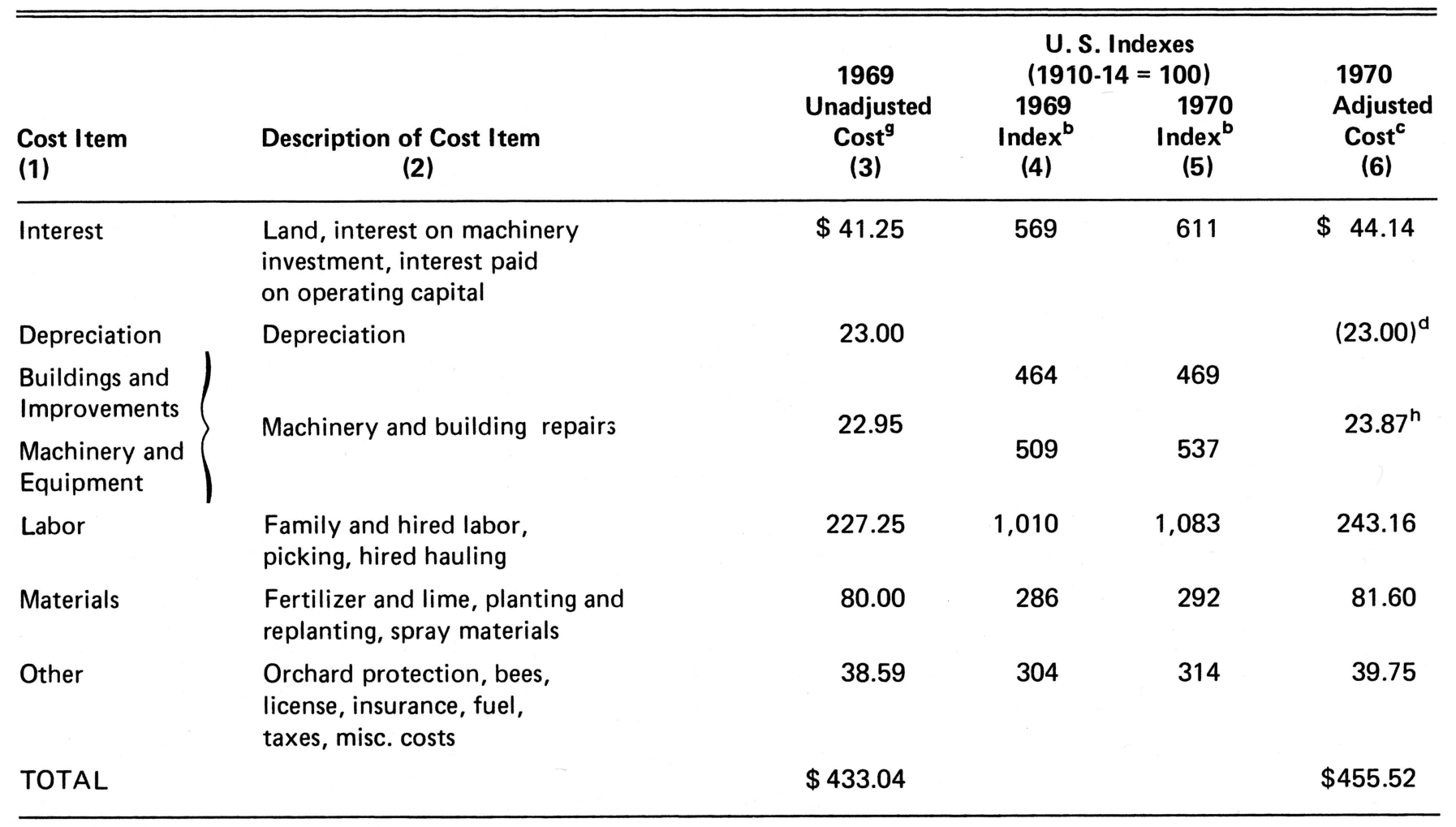




\section{APPENDIX TABLE D (Continued)}

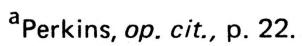

${ }^{b}$ U. S. Department of Agriculture, Statistical Reporting Service, Crop Reporting Board, Agricultural Prices, 1970 Annual Summary (Washington: U. S. Government Printing Office, 1971) pp. 8 and 11.

${ }^{\mathrm{c} C a l c u l a t e d}$ by dividing data in column (5) by data in column (4) and multiplying by data in column (3) .

${ }^{\mathrm{d}}$ Depreciation costs were not updated.

$\infty \quad{ }^{\mathrm{e}}$ Average depreciation in these studies of 8.75 per cent of total cost was used to partition a general overhead cost of $\$ 45$ into these two categories. ${ }^{f}$ Kearl and Snyder, loc. cit.

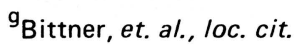

${ }^{\mathrm{h}}$ Calculated by dividing data in column (5) by data in column (4) for each category, averaging the results, and multiplying by data in column (3). 'Kelsey, loc. cit.

${ }^{j}$ Zuroske, op. cit., p. 2.

${ }^{\mathrm{K}} \mathrm{Green}$, et. al., loc. cit.

'Burlingame and Koch, loc. cit. 


\section{APPENDIX TABLE E}

DATA USED TO COMPUTE ALTERNATIVE II ACREAGES

\begin{tabular}{|c|c|c|c|c|c|}
\hline $\begin{array}{l}\text { Production } \\
\text { Region } \\
\text { (1) }\end{array}$ & $\begin{array}{l}1969 \text { Commercial } \\
\text { Apple Crop }{ }^{\mathrm{a}} \\
\text { (2) }\end{array}$ & $\begin{array}{l}\text { Quantity Used } \\
\text { Fresh }^{\text {a }} \\
\text { (3) }\end{array}$ & $\begin{array}{l}\text { Portion Used } \\
\text { Fresh } \\
\text { (4) }\end{array}$ & $\begin{array}{c}\text { Alternative I } \\
\text { Acreage Constraints } \\
\text { (5) }\end{array}$ & $\begin{array}{c}\text { Alternative II } \\
\text { Acreage Constraints } \\
\text { (6) }\end{array}$ \\
\hline & Million Pounds & Million Pounds & Per Cent & Acres & Acres \\
\hline New England & 289.2 & 246.2 & 85.13 & 27,979 & 23,818 \\
\hline New York & 855.0 & 347.8 & 40.68 & 74,376 & 30,256 \\
\hline Pennsylvania & 525.0 & 139.6 & 26.59 & 38,558 & 10,253 \\
\hline Virginia & 472.0 & 179.6 & 38.05 & 37,206 & 14,157 \\
\hline West Virginia & 260.0 & 126.8 & 48.77 & 19,100 & 9,315 \\
\hline Michigan & 720.0 & 287.0 & 39.86 & 76,000 & 30,294 \\
\hline Washington & $1,645.0$ & $1,180.0$ & 71.73 & 92,244 & 66,167 \\
\hline Oregon & 167.0 & 116.3 & 69.64 & 7,254 & 5,052 \\
\hline California & 540.0 & 126.0 & 23.33 & 26,120 & 6,094 \\
\hline
\end{tabular}

${ }^{a}$ Taken from U. S. Department of Agriculture, Agricultural Statistics, 1970, (Washington: U. S. Government Printing Office, 1970 ) p. 211.

${ }^{\mathrm{b}}$ Taken from Table 6.

${ }^{\mathrm{c}}$ Computed by multiplying column (5) by column (4). 
APPENDIX TABLE F

REPORTED PER CAPITA FRESH APPLE CONSUMPTION, 1909 to $1969^{a}$

\begin{tabular}{|c|c|c|c|}
\hline Year & $\begin{array}{l}\text { Per Capita } \\
\text { Consumption } \\
\text { (Pounds) }\end{array}$ & Year & $\begin{array}{r}\text { Per Capita } \\
\text { Consumption } \\
\text { (Pounds) }\end{array}$ \\
\hline $\begin{array}{l}1909 \\
1910 \\
1911 \\
1912\end{array}$ & $\begin{array}{l}62.2 \\
59.4 \\
73.5 \\
74.6\end{array}$ & $\begin{array}{l}1939 \\
1940 \\
1941 \\
1942\end{array}$ & $\begin{array}{l}30.7 \\
29.7 \\
31.7 \\
28.1\end{array}$ \\
\hline $\begin{array}{l}1913 \\
1914 \\
1915 \\
1916 \\
1917 \\
1918 \\
1919 \\
1920 \\
1921 \\
1922 \\
1923 \\
1924 \\
1925 \\
1926 \\
1927 \\
1928 \\
1929 \\
1930 \\
1931 \\
1932 \\
1933 \\
1934 \\
1935 \\
1936 \\
1937 \\
1938\end{array}$ & $\begin{array}{l}59.3 \\
71.8 \\
69.0 \\
63.9 \\
56.1 \\
56.9 \\
45.2 \\
63.0 \\
36.1 \\
57.5 \\
54.7 \\
54.1 \\
46.3 \\
62.3 \\
37.4 \\
48.9 \\
39.7 \\
42.1 \\
51.7 \\
39.2 \\
40.0 \\
25.3 \\
32.9 \\
27.6 \\
33.6 \\
28.2\end{array}$ & $\begin{array}{l}1943 \\
1944 \\
1945 \\
1946 \\
1947 \\
1948 \\
1949 \\
1950 \\
1951 \\
1952 \\
1953 \\
1954 \\
1955 \\
1956 \\
1957 \\
1958 \\
1959 \\
1960 \\
1961 \\
1962 \\
1963 \\
1964 \\
1965 \\
1966 \\
1967 \\
1968 \\
1969\end{array}$ & $\begin{array}{l}24.9 \\
25.5 \\
22.9 \\
23.0 \\
25.4 \\
26.3 \\
25.0 \\
23.2 \\
25.9 \\
21.9 \\
21.0 \\
20.1 \\
20.0 \\
19.3 \\
19.3 \\
22.5 \\
21.9 \\
18.2 \\
16.4 \\
17.4 \\
16.7 \\
17.8 \\
16.3 \\
15.9 \\
16.1 \\
15.6 \\
15.0\end{array}$ \\
\hline
\end{tabular}

Sources: U. S. Department of Agriculture, Agricultural Statistics, 1960. p. 208; 1962. p. 246; 1970. p. 258. (Washington: U. S. Government Printing Office, 1960, 1962, 1970). 


\begin{tabular}{|c|c|}
\hline $\begin{array}{l}\text { Consumption } \\
\text { Region }\end{array}$ & $\begin{array}{c}1985 \\
\text { Population Estimate } \\
\text { (thousands) }\end{array}$ \\
\hline 1 New England & 13,281 \\
\hline $2 N Y$ & 21,416 \\
\hline 3 PA & 12,291 \\
\hline $4 \mathrm{NJ}$ & 9,053 \\
\hline 5 DE-MD & 5,572 \\
\hline 6 WV & 1,667 \\
\hline 7 VA & 5,618 \\
\hline 8 NC-SC-GA & 14,148 \\
\hline $9 \mathrm{FL}$ & 9,650 \\
\hline $10 \mathrm{MI}$ & 9,728 \\
\hline 11 WI-IL-IN & 23,296 \\
\hline $12 \mathrm{OH}$ & 12,364 \\
\hline $13 \mathrm{KY}-\mathrm{TN}$ & 7,891 \\
\hline 14 AR-LA-MS-AL & 13,482 \\
\hline 15 ND-SD-MN & 5,544 \\
\hline 16 NE-IA-KS-MO & 11,811 \\
\hline 17 OK-TX & 16,078 \\
\hline 18 MT-ID-WY & 2,009 \\
\hline 19 NV-UT-CO-AZ-NM & 8,642 \\
\hline 20 WA & 3,607 \\
\hline 21 OR & 2,378 \\
\hline $22 \mathrm{CA}$ & 28,998 \\
\hline TOTAL & 238,524 \\
\hline
\end{tabular}

${ }^{a}$ Derived from: Bureau of the Census, Revised Projections of the Population of States, 1970 to 1985 (Washington: U. S. Government Printing Office, 1967), pp. 43-49. 


\section{APPENDIX TABLE H}

AGGREGATE PRODUCTION AND TRANSPORTATION COSTS

FOR THE BASIC MODEL AND SIX ALTERNATIVES

\begin{tabular}{cc}
\hline \hline Alternative & $\begin{array}{c}\text { Aggregate Production } \\
\text { and Transportation Costs } \\
\text { (millions) }\end{array}$ \\
\hline Basic Model & $\$ 121.8$ \\
I & 121.8 \\
II & 148.8 \\
III & 155.7 \\
IV & 145.6 \\
V & 143.5 \\
VI & 97.8 \\
\hline
\end{tabular}


[Blank Page in Original Bulletin] 
[Blank Page in Original Bulletin] 